\title{
Decision-making in aesthetics: root coverage revisited
}

\author{
Philippe Bouchard, Jacques Malet \& Alain Borghetti
}

Over the years, numerous surgical techniques have been introduced to correct labial, gingival recession defects. Aesthetic concerns are usually the reason to perform these procedures. Clinical studies have evaluated many of the techniques. The depths of the defects have been measured before surgery and at a follow-up examination after 6 months or later. Results in terms of mid-surface root coverage have been expressed in millimeters and as the percentage of original defect that has been covered. Also, percentage defects with complete coverage have often been reported.

The results of available studies have been evaluated $(30,117,119)$. Mean root coverage for the treated patient groups ranges from around $50 \%$ to close to $100 \%$ of the original defect depth. Mean root coverages of $70-80 \%$ seem most common. Complete root coverages have been achieved in about $50 \%$ of the treated defects. These results were confirmed by our own updated review and compilation of data from the literature (Tables 1,2). There seems to be no clear difference in the effectiveness of the various techniques using these methods of evaluation.

Previous research has focused on evaluations and comparisons of various techniques. Few attempts have been made to identify factors of importance for success or failure. Therefore, the clinician receives little guidance from the literature in decision-making on the individual case. In addition, results have only been assessed by millimeter and percentage data. The overall aesthetic outcome - also depending on final color and tissue blend of the grafted area - has not been systematically evaluated. It has merely been remarked upon using general terms such as "aesthetically pleasing" and "good aesthetic results". This lack of information adds to the difficulties in the selection of best procedure for the individual case.

At this stage, thus, decision-making for root coverage procedures can only partly be based upon scientific evidence. Therefore, this chapter also focuses on

Table 1. Mean percentage of root coverage in Class I and Class II defects: summary of data from comparative and non-controlled case studies. Selection criteria: 6-month minimum follow-up, at least 10 patients per group, initial recession depth data available

\begin{tabular}{|c|c|c|c|c|c|c|c|}
\hline Procedure & $\begin{array}{l}\text { Number } \\
\text { of } \\
\text { selected } \\
\text { studies }\end{array}$ & $\begin{array}{l}\text { Number } \\
\text { of } \\
\text { study } \\
\text { groups }\end{array}$ & $\begin{array}{l}\text { Number } \\
\text { of } \\
\text { patients }\end{array}$ & $\begin{array}{l}\text { Number } \\
\text { of } \\
\text { teeth }\end{array}$ & $\begin{array}{l}\text { Maximum } \\
\text { length of } \\
\text { studies } \\
\text { in months }\end{array}$ & $\begin{array}{l}\text { Mean initial } \\
\text { recession } \\
\text { depth in } \mathrm{mm} \\
\text { (range) }\end{array}$ & $\begin{array}{l}\text { Mean \% of } \\
\text { root coverage } \\
\text { (range) }\end{array}$ \\
\hline Rotational flaps ${ }^{\mathrm{a}}$ & 6 & 8 & 121 & 127 & 36 & $3.9(3.1-5.0)$ & $66(41-82)$ \\
\hline Advanced flaps ${ }^{b}$ & 6 & 7 & 119 & 244 & 96 & $3.7(3.3-4.1)$ & 77 (55-98) \\
\hline $\begin{array}{l}\text { Submerged grafts } \\
\text { + } \text { rotational flaps }^{\mathrm{c}} \\
\text { + coronally positioned flap }{ }^{\mathrm{d}} \\
\text { Envelope }^{\mathrm{e}}\end{array}$ & $\begin{array}{r}5 \\
11 \\
4\end{array}$ & $\begin{array}{r}5 \\
13 \\
4\end{array}$ & $\begin{array}{r}137 \\
246 \\
50\end{array}$ & $\begin{array}{r}170 \\
281 \\
64\end{array}$ & $\begin{array}{l}18 \\
60 \\
48\end{array}$ & $\begin{array}{l}3.9(3.3-4.9) \\
4.0(3.0-5.6) \\
2.9(2.5-3.4)\end{array}$ & $\begin{array}{l}83(70-97) \\
82(52-99) \\
83(80-87)\end{array}$ \\
\hline $\begin{array}{l}\text { Guided tissue regeneration te } \\
\text { Nonresorbable membrane } \mathrm{f}^{\mathrm{f}} \\
\text { Resorbable membrane }^{\mathrm{g}}\end{array}$ & $\begin{array}{l}\text { techniques } \\
10 \\
7\end{array}$ & $\begin{array}{r}10 \\
8\end{array}$ & $\begin{array}{r}201 \\
98\end{array}$ & $\begin{array}{l}201 \\
104\end{array}$ & $\begin{array}{l}48 \\
12\end{array}$ & $\begin{array}{l}5.0(3.3-6.3) \\
4.25(3.1-5.8)\end{array}$ & $\begin{array}{l}76(54-87) \\
74(48-92)\end{array}$ \\
\hline $\begin{array}{l}\text { Selected studies: } \\
\text { a } 24,25,33,40,98,123 . \\
\text { b2, } 64,67,91,113,118 \\
\text { c } 15,16,46,48,88 . \\
\text { d } 16,17,19,20,49,61,78,93,116,118, \\
\text { e } 4,58,72,86 . \\
\text { f } 58,83,89,90,107,108,109,111,112, \\
\text { g } 17,48,49,63,89,116,125 .\end{array}$ & 125. & & & & & & \\
\hline
\end{tabular}


Table 2. Mean percentage of teeth with complete root coverage in Class I and Class II defects: summary of data from comparative and non-controlled case studies. Selection criteria: 6-month minimum follow-up, at least 10 patients per group, initial recession depth data available

\begin{tabular}{|c|c|c|c|c|c|c|}
\hline Procedure & $\begin{array}{l}\text { Number } \\
\text { of selected } \\
\text { studies* }\end{array}$ & $\begin{array}{l}\text { Number } \\
\text { of study } \\
\text { groups }\end{array}$ & $\begin{array}{l}\text { Number } \\
\text { of patients }\end{array}$ & $\begin{array}{l}\text { Number } \\
\text { of teeth }\end{array}$ & $\begin{array}{l}\text { Maximum } \\
\text { length of } \\
\text { studies in } \\
\text { months }\end{array}$ & $\begin{array}{l}\text { \% teeth with } \\
\text { complete root } \\
\text { coverage } \\
\text { (range) }\end{array}$ \\
\hline Rotational flaps & - & - & - & - & - & - \\
\hline Advanced flaps ${ }^{\mathrm{a}}$ & 6 & 7 & 119 & 244 & 96 & $45(9-84)$ \\
\hline $\begin{array}{l}\text { Submerged grafts } \\
\text { + rotational flaps }{ }^{\mathrm{b}} \\
\text { + coronally positioned flap } \\
\text { Envelope }^{\mathrm{d}}\end{array}$ & $\begin{array}{l}2 \\
8 \\
4\end{array}$ & $\begin{array}{l}2 \\
8 \\
4\end{array}$ & $\begin{array}{r}84 \\
205 \\
50\end{array}$ & $\begin{array}{r}110 \\
223 \\
64\end{array}$ & $\begin{array}{r}6 \\
60 \\
48\end{array}$ & $\begin{array}{l}89.5(89-90)^{* *} \\
56(50-88) \\
53(42-62)\end{array}$ \\
\hline $\begin{array}{l}\text { Guided tissue regeneration } \\
\text { Nonresorbable membrane } \\
\text { Resorbable membrane }^{\mathrm{e}}\end{array}$ & $\begin{array}{l}\text { chniques } \\
6 \\
5\end{array}$ & $\begin{array}{l}6 \\
5\end{array}$ & $\begin{array}{l}84 \\
64\end{array}$ & $\begin{array}{l}84 \\
70\end{array}$ & $\begin{array}{l}48 \\
12\end{array}$ & $\begin{array}{l}33(0-47) \\
44(8-72)\end{array}$ \\
\hline
\end{tabular}

*The numbers of studies in this table are reduced compared to Table 1, since the percentage of defects with complete coverage has not always been reported.

**One operator performed all procedures.

Selected studies:

a 2, 64, 67, 91, 113, 118

b $46,48$.

c $19,20,49,61,78,116,118$.

$\mathrm{d} 4,58,72,86$.

e $58,89,90,107,111,125$.

f $48,49,89,116,125$.

the "unknowns" - overall aesthetic outcome and factors of relevance for successfull results of the individual case. It should be realized that many opinions and recommendations presented here are primarily - and by necessity - based on our personal clinical experiences. Nevertheless, we feel that careful decision-making prior to root coverage procedures will enhance the success rate for these efforts.

Table 3. Root coverage techniques

\begin{tabular}{l}
\hline Pedicle soft tissue grafts \\
- Rotational flaps \\
Laterally positioned flap \\
Double papilla flap \\
- Advanced flaps \\
Coronally positioned flap \\
Semilunar flap \\
\hline Free soft tissue grafts \\
- Nonsubmerged graft \\
One stage (free gingival graft) \\
Two stage (free gingival graft + coronally positioned \\
flap) \\
- Submerged grafts \\
Connective tissue graft + laterally positioned flap \\
Connective tissue graft + double papilla flap \\
Connective tissue graft + coronally positioned flap \\
(subepithelial connective tissue graft) \\
Envelope techniques \\
\hline Additive treatments \\
- Root surface modification agents \\
- Gnamel matrix proteins \\
Nonresorbable membrane barriers \\
Resorbable membrane barriers
\end{tabular}

\section{Root coverage techniques}

Currently, numerous surgical techniques are proposed for root coverage (Table 3).

\section{Pedicle soft tissue grafts}

Soft tissues adjacent to the recession area are positioned over the defect.

\section{Rotational flaps}

The displacement is a lateral movement of rotation. At first it was described as the "lateral sliding flap"

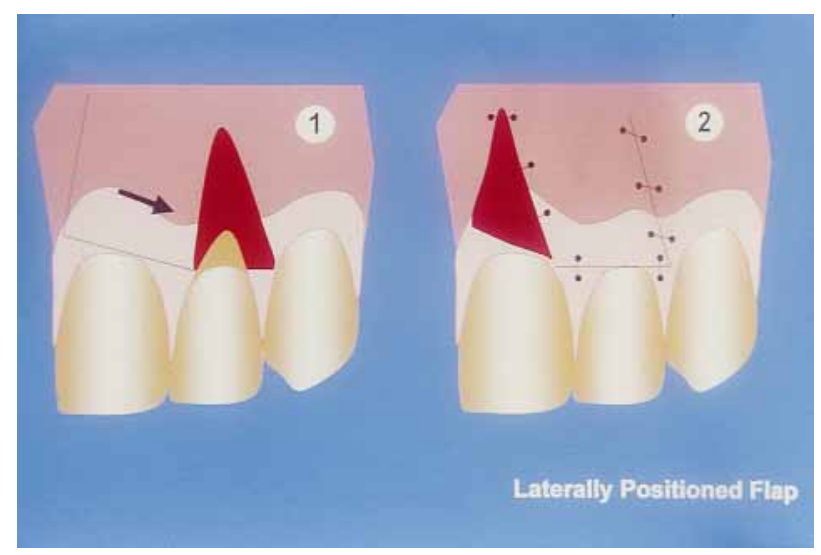

Fig. 1. Schematic drawing of laterally positioned flap technique 

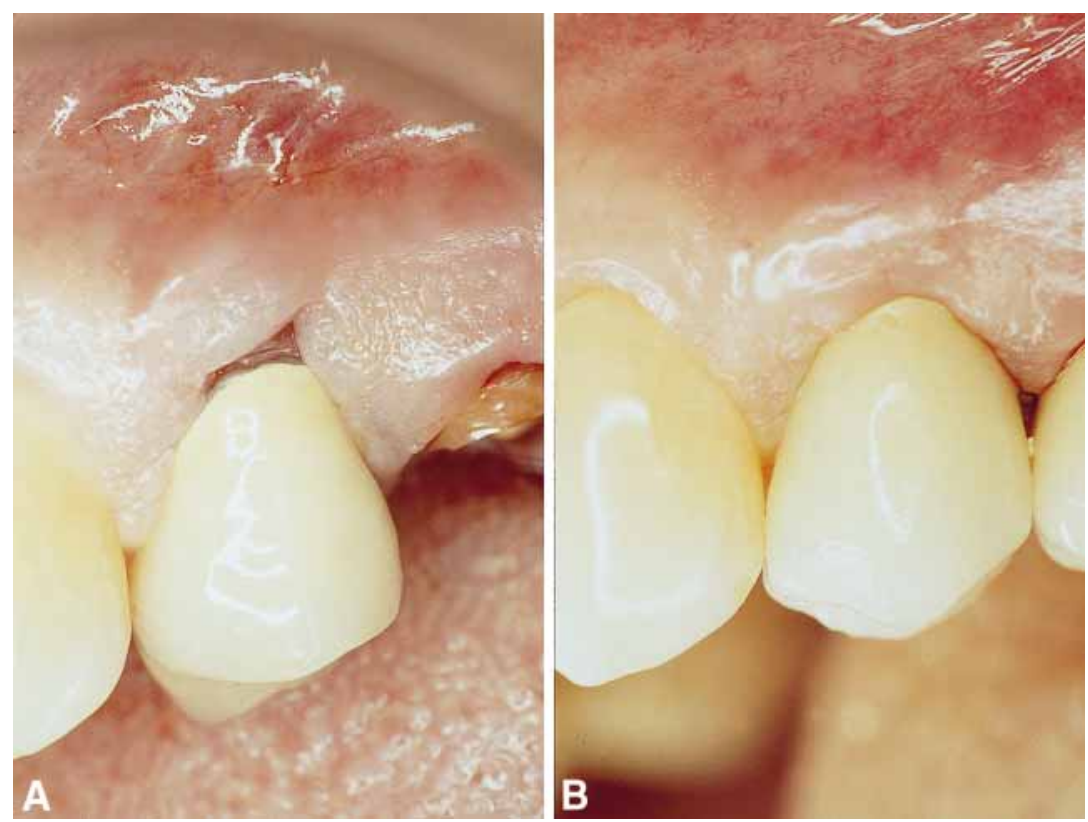

Fig. 2. A. Shallow-narrow recession defect. The base of the cleft is located in the alveolar mucosa (Miller Class II). Gingival augmentation is needed to cover the prosthetic margin. B. Increased dimension of the gingiva; 27 months post-treatment following laterally positioned flap.

(38). The procedure was then improved, and named: the laterally positioned flap $(39,99)$ (Fig. 1, 2). The "oblique rotational flap" (80), the "rotation flap" (79) and the "transpositioned flap" (9) are modifications in incision design. When the lateral movement is both mesial and distal to the defect, the rotational flap is called a double papilla flap (26) (Fig. 3).

\section{Advanced flaps}

The displacement is a vertical movement in a coronal direction. The semilunar flap (102) differs from the coronally positioned flap $(2,47,67,91,118)$ in the incision design and in the placement of sutures (Fig. 4, 5).

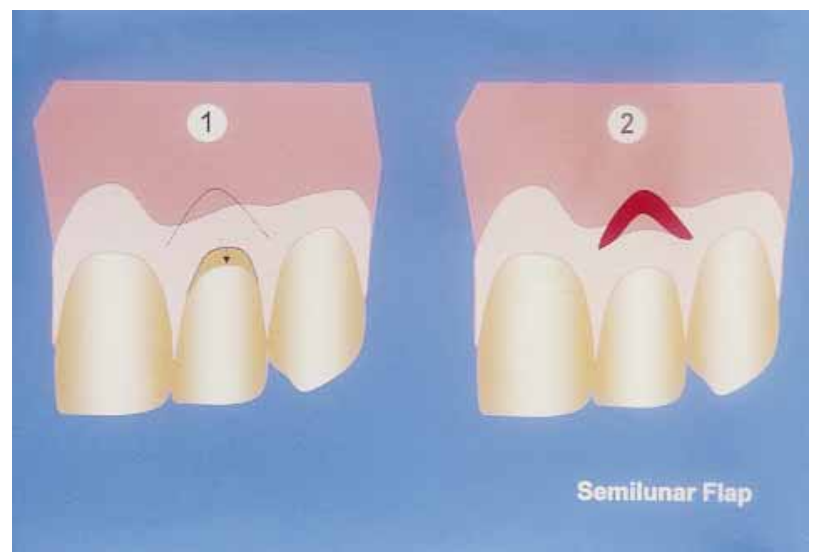

Fig. 4. Schematic drawing of semilunar flap technique

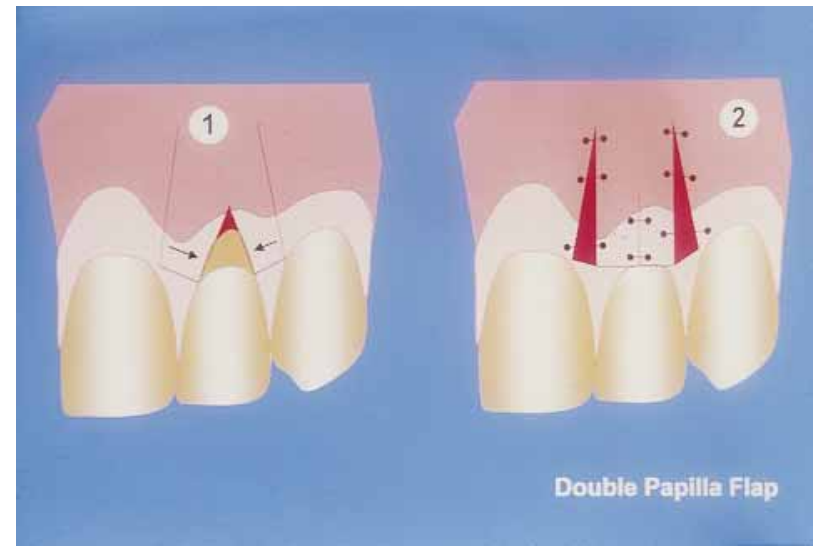

Fig. 3. Schematic drawing of double papilla flap technique

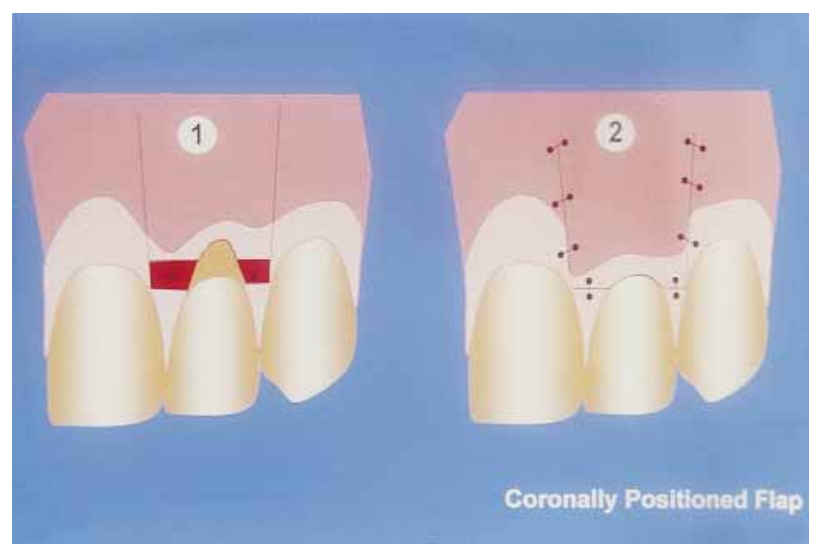

Fig. 5. Schematic drawing of coronally positioned flap technique 


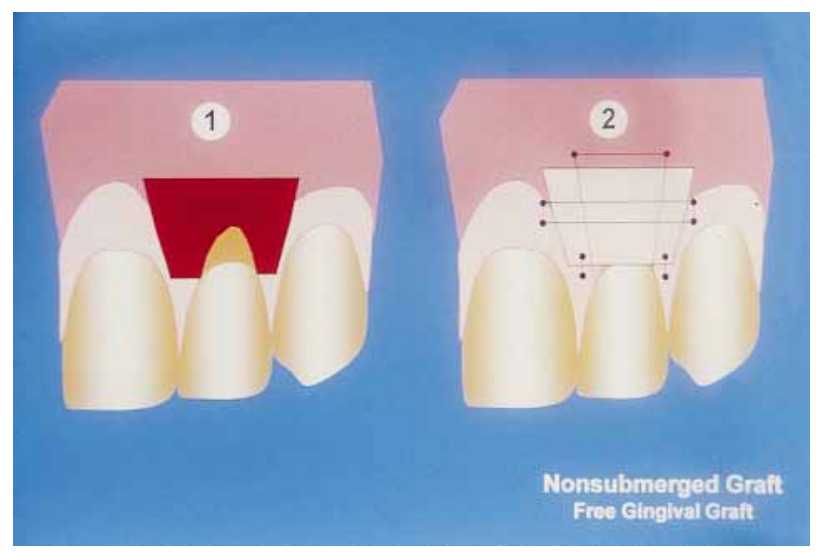

Fig. 6. Schematic drawing of nonsubmerged graft technique
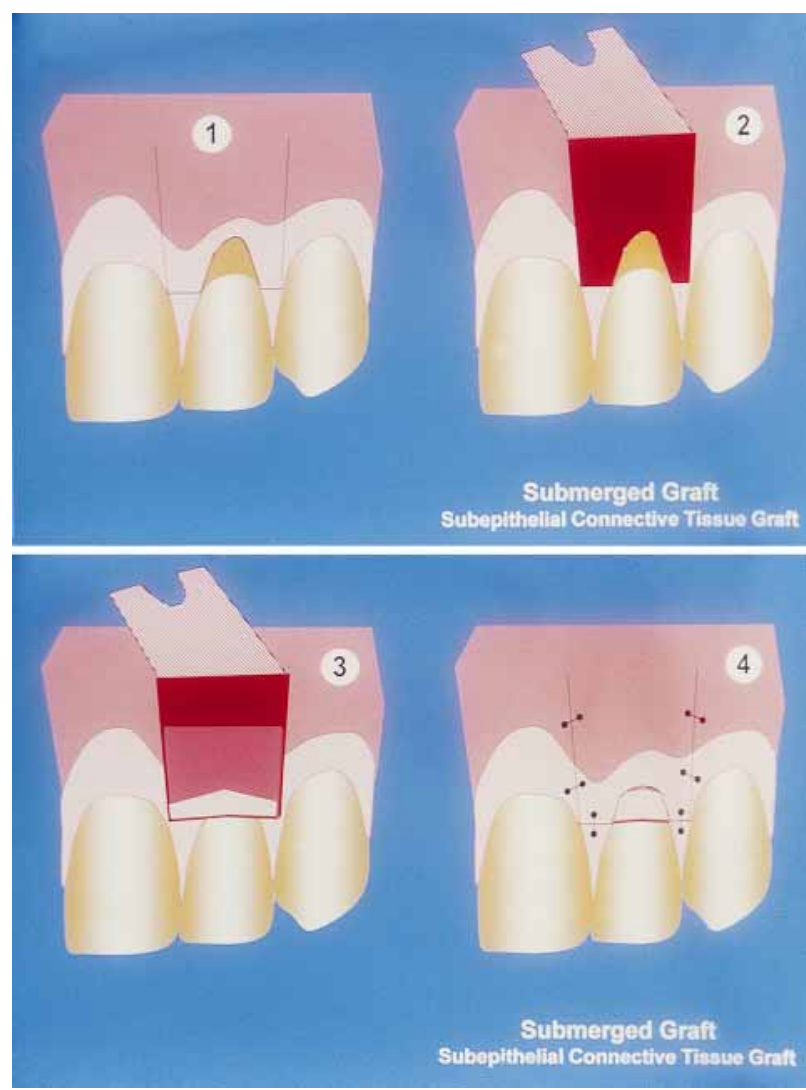

Fig. 7. Schematic drawing of subepithelial connective tissue graft technique.

\section{Free soft tissue grafts}

Soft tissues are transferred from an area distant to the recession to cover the defect. The graft can be nonsubmerged: that is, placed on the surface of the recipient bed; or submerged, when the graft is completely or partially covered by the flap.

\section{Nonsubmerged grafts}

The epithelialized soft tissue graft is commonly named free gingival graft $(13,14,54,56,66,69,110)$ (Fig. 6). A two-step procedure has also been described $(12,24,50,59,104)$. First, gingival augmentation is achieved by a free gingival graft. Secondly, after the graft has healed, a coronally positioned flap is performed to cover the recession defect.

\section{Submerged grafts}

The subeptithelial connective tissue graft combines a free connective tissue graft with pedicle soft tissue grafts (Fig. 7). Numerous modifications have been described in the literature.

To cover the graft, laterally positioned flaps (73, 88 ) or double papilla flaps $(15,45,46,48)$ have been proposed. However, a coronally positioned flap is most commonly used $(17,19,36,60,61,78$, $93,116,118,125)$. Horizontal incisons have been suggested to avoid vertical releasing incisons (23, 49, 57) (Fig. 8, 9). An envelope technique with (72) or without (86) vertical incisions has been also proposed (Fig. 10). A modification of the envelope technique, the tunnel approach, has been described for combined treatment of adjacent recessions (3, 4, 122) (Fig. 11, 12).

Initially, partially epithelialized connective tissue grafts were used; the epithelial border of the graft was not excised, but left coronal to the border of the flap. In order to enhance the esthetic results, it has been suggested to remove the epithelial collar and completely immerse the graft under the flap $(19,20)$ (Fig. 13, 14).

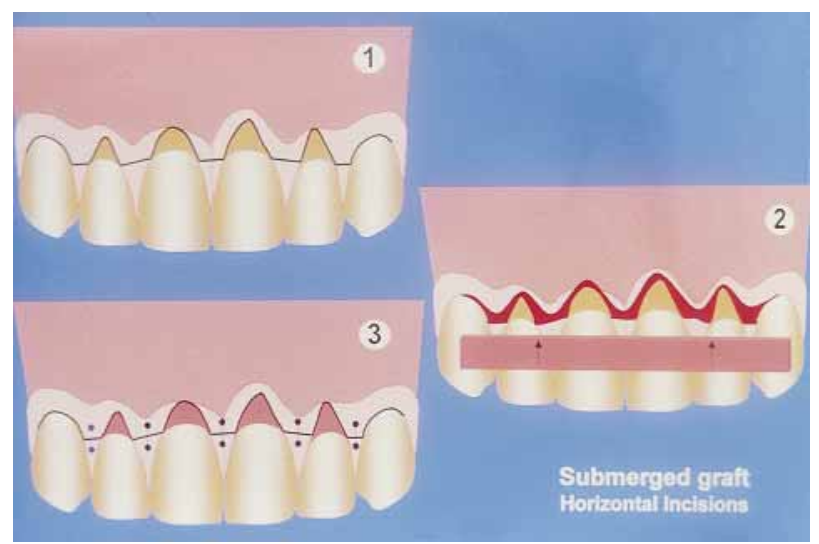

Fig. 8. Schematic drawing of submerged graft technique with horizontal incisions. 

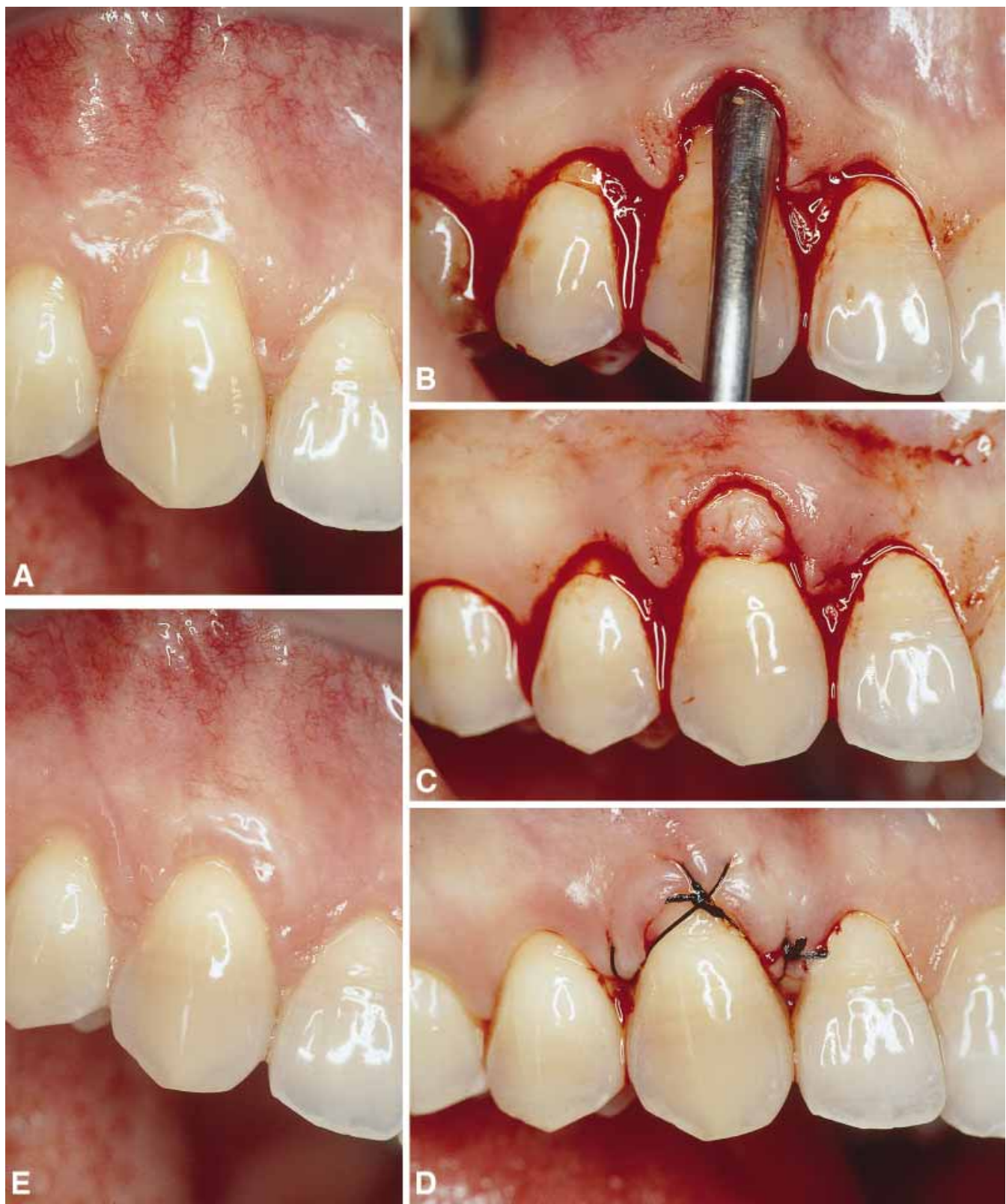

Fig. 9. A. Moderate-wide recession defect on the maxillary canine (Miller Class I). No gingival augmentation is required. B. Preparation of the recipient site. Two horizontal incisions are made at the cementoenamel junction level, mesial and distal to the defect. C. A connective tissue graft, without epithelial band, is placed beneath the flap. D. The embedded graft is secured by the coronally positioned flap. E. 2 years post-surgery.

\section{Additive treatments}

In order to improve the biological link between the root surface and the covering soft tissues, additive treatments have been explored.

\section{Root surface modification agents}

Chemical biomodification has centered on the use of citric acid $(2,13,14,19,25,45,56,57,59,62,69$,
$74,110)$ and tetracycline hydrochloride $(20,23,45-$ $47,49,111)$. It has been recommended to rub the roots with $\mathrm{pH} 1$ citric acid for $3 \mathrm{~min}$ or with tetracycline $\mathrm{HCl}(50-125 \mathrm{mg} / \mathrm{ml}$ for 3-5 $\mathrm{min})$.

\section{Enamel matrix proteins}

Enamel matrix proteins gel is applied onto root surfaces previously conditioned for 2 min with a $24 \%$ EDTA containing gel (42). 


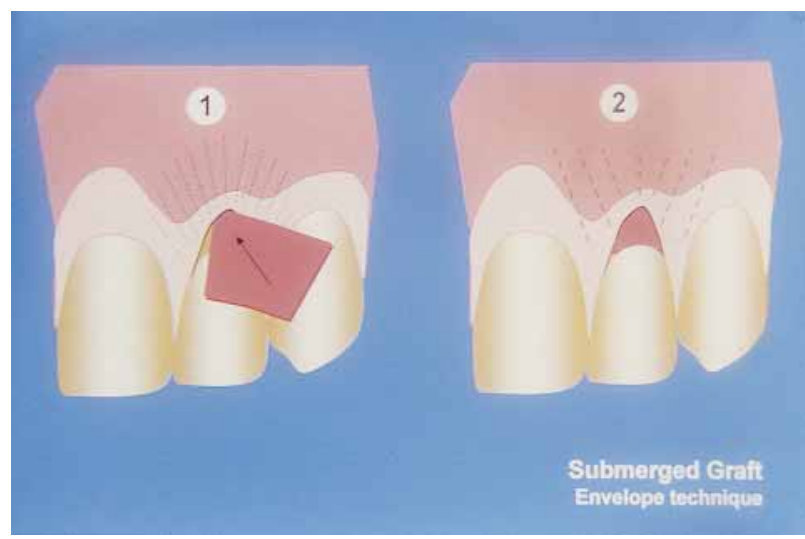

Fig. 10. Schematic drawing of the envelope technique

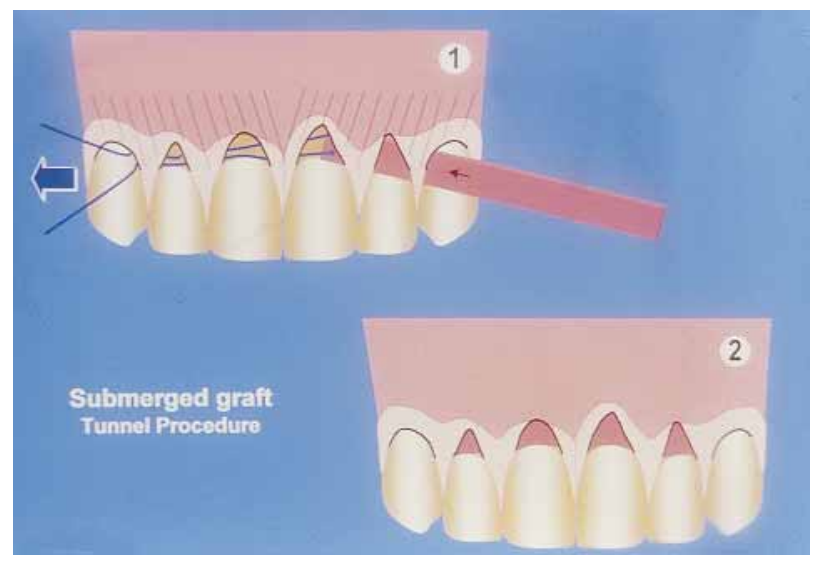

Fig. 11. Schematic drawing of the tunnel approach. The graft is pulled through the tunnel with a suture.

\section{Guided tissue regeneration}

A membrane barrier is placed beneath a coronally positioned flap to cover the area of the recession.

\section{Nonresorbable membrane barriers}

Expanded polytetrafluoroethylene membrane barriers were first used $(81,106-108,112)$. To provide a space between the membrane and the root, a teflon suture in mesiodistal direction through the membrane $(81,88,125)$, a gold frame bent under the membrane (108), or the use of miniscrews (90) was suggested. Specially designed titanium-reinforced expanded polytetrafluoroethylene membrane barriers have also been tested $(58,109)$.

\section{Resorbable membrane barriers}

Various absorbable biomaterials for guided tissue regeneration devices have been used in the compo- sition of membrane barriers. Polylactic acid and citric acid ester $(17,35,36,48,49,63,82,88,115,125)$, polylactic-polyglycolic acid copolymer (116), polyglactin $910(28,85)$, and collagen $(96,101,124)$ have been subjected to clinical evaluation (Fig. 15).

\section{Healing events affecting aesthetic outcome}

From a periodontal standpoint, Egelberg initiated the basic principles of wound healing in 1987 (29). More recently, periodontal wound healing was emphasized and reviewed by Wikesjö \& Selvig (121). Although the healing pattern in recession defects is somewhat different from intrabony or furcation defects, the biological principles of healing remain the same. Surgical guidelines can be deduced from these principles (Table 4).

\section{Histocompatibility}

Root surface cementum of a recession defect is usually contaminated by exposure to the oral environment. The longer the roots have been exposed, the more the surface changes (95). As yet, no clinical study has explored the influence of the duration of

Table 4. Surgical guidelines related to biological principles of healing in root coverage procedures

\begin{tabular}{l}
\hline Histocompatibility \\
Decontamination of exposed root surfaces \\
\hline Vascularization \\
Careful surgical manipulation of the soft tissues \\
Graft larger than the coronal width of the recession \\
defect \\
Lateral extension of the vascular bed according to the \\
surface area of the defect \\
Vertical incisions over a vascular bed \\
No sutures over the root surface \\
Wound stability \\
No graft mobility \\
Passive adaptation of the covering flap onto the \\
recession defect \\
3 to 5 minutes finger pressure on the operated area \\
Suture removal after 10 to 14 days \\
No brushing or chewing on the operated area for 3 weeks \\
\hline Wound contraction \\
Coronal margin of the flap secured up to or beyond the \\
cementoenamel junction \\
\hline Wound asepsis \\
No periodontal dressing \\
Postoperative anti-infective care program \\
$0.12 \%$ chlorhexidine rinse, twice daily during \\
the first 2 weeks \\
Application of chlorhexidine gel onto the \\
operated area for another 2 weeks \\
\hline
\end{tabular}



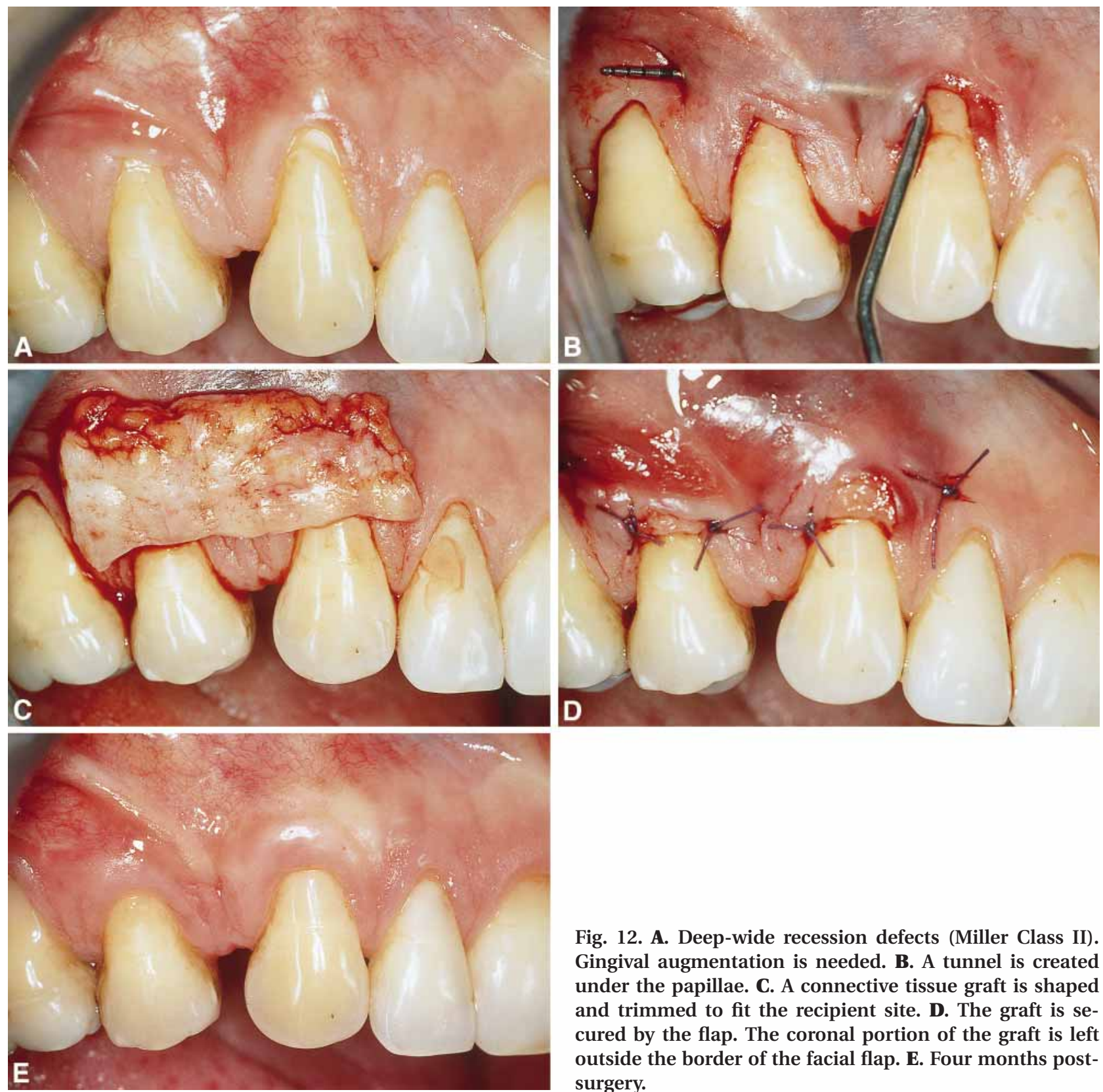

Fig. 12. A. Deep-wide recession defects (Miller Class II). Gingival augmentation is needed. B. A tunnel is created under the papillae. C. A connective tissue graft is shaped and trimmed to fit the recipient site. D. The graft is secured by the flap. The coronal portion of the graft is left outside the border of the facial flap. E. Four months postsurgery.

root exposure for the outcome of root coverage procedures.

The removal of the biofilm on the exposed portion of the root appears to be of importance for healing (77). It now appears that previously suggested extensive root flattening is not required. Thus, gentle root planing must render the root surface free from $\mathrm{mi}-$ crobial plaque (32). Root reduction before root coverage therapies is only indicated for anatomical reasons, such as root prominence, or caries removal (119). Recently, the results of a comparative study suggest that root planing is not necessary in shallow recession defects treated with coronally positioned

flap (84). Polishing the exposed root surface resulted in similar clinical outcome.

\section{Vascularization}

In root coverage procedures, the avascular surface of the root presents a challenge for wound healing. Blood supply following flap operations will have to come from the areas bordering the recession defect and from the pedicle (70). The healing of nonsubmerged graft primarily depends on the restoration of collateral circulation from the periosteal connective tissue bed bordering the defect. Thus, 


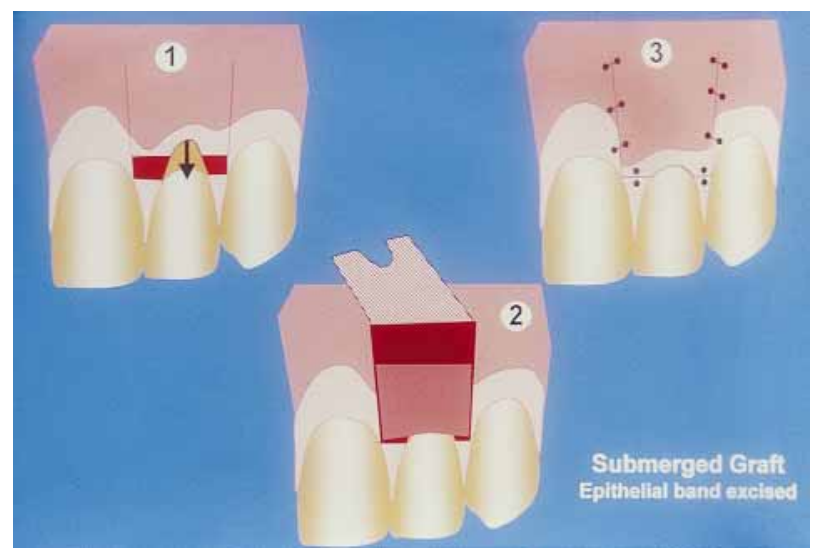

Fig. 13. Schematic drawing of submerged graft technique without epithelial collar

the size of the defect relative to the connective tissue bed determines the survival of nonsubmerged graft $(75,100)$.

A recent case-series indicates that flap thickness is associated with frequency of complete root coverage in coronally positioned flap procedures (10). The thinner the soft tissues, the more difficult the procedure and higher the risk of postoperative necrosis. When tissues are thin, particular attention should be payed to ensure a large vascular bed.

Clinical studies have also demonstrated that the thickness of the graft plays a major role in graft survival $(14,69)$. Submerged grafts maximize soft tissue survival by providing a double blood supply from the overlying flap and the periosteal connective tissue bed.

\section{Wound stability}

It has been demonstrated that the initial adhesion of the clot to the root surface is of critical importance in the healing process (120). A thin clot promotes tensile strength and stability of the wound. The surgical technique and the early postoperative period are the keystones to achieving successful root coverage. It is our personal experience that failures primarily occur within the first week after surgery.

\section{Wound contraction}

Wound contraction is a major event occurring during the formation of granulation tissue. In large wounds, $5-10 \%$ reduction can be observed (11). Undesirable postoperative recession can be avoided by suturing the flap 1 to $2 \mathrm{~mm}$ coronal to the cementoenamel junction.

\section{Wound asepsis}

In addition to mechanical disruption of the wound, persistent inflammation and/or infections may affect the healing process. The postoperative care program should be based on infection control using topical antimicrobial agents. Systemic antibiotic therapy might be reserved for membrane procedures (97). We rarely use periodontal dressings (18). They may increase local temperature, humidity and stagnation, favoring the development of bacterial biofilms (21). It should be added, however, that there are no clinical studies available evaluating different postoperative procedures.

\section{Aesthetic evaluation of outcome}

\section{Patient's own evaluation}

It is the patient, not the surgeon, who primarily should judge the success of root coverage procedures. Thus, a key metric should be patient satisfaction. For other conditions, such qualitative outcome is usually measured by Visual Analog Scales, other scores or questionnaires. Surprisingly, this has not been part of the available literature. A system for patient's own evaluation, adapted to root coverage procedures, is highly needed and should be included in future research.

\section{Professional evaluation}

As mentioned above, defect coverage by soft tissue in millimeters and percentages has so far been the main outcome variables in clinical studies. However, in terms of aesthetics, the percentage of teeth with complete root coverage seems more important and should be considered as a prerequisite for success. Furthermore, comparative data have been based on

Fig. 14. A. Moderate-narrow/wide recesion defects on the canine and the first premolar (Miller Class I). Gingival augmentation is not required. The patient's concern is esthetic although recessions are in a non-visible area. B. After preparing the recipient site, the graft is removed from the palate. C. Connective tissue wedge with an easily identified epithelial collar. D. The small band of epithelium is excised. E. Wound edges at the donor site are sutured. F. The connective tissue graft is placed over the denuded root surface, and secured up to the cementoenamal junction. Note that a single mesial vertical releasing incision is made. G. The flap is coronally positioned in order to completely immerse the graft. H. Three years postsurgery. 

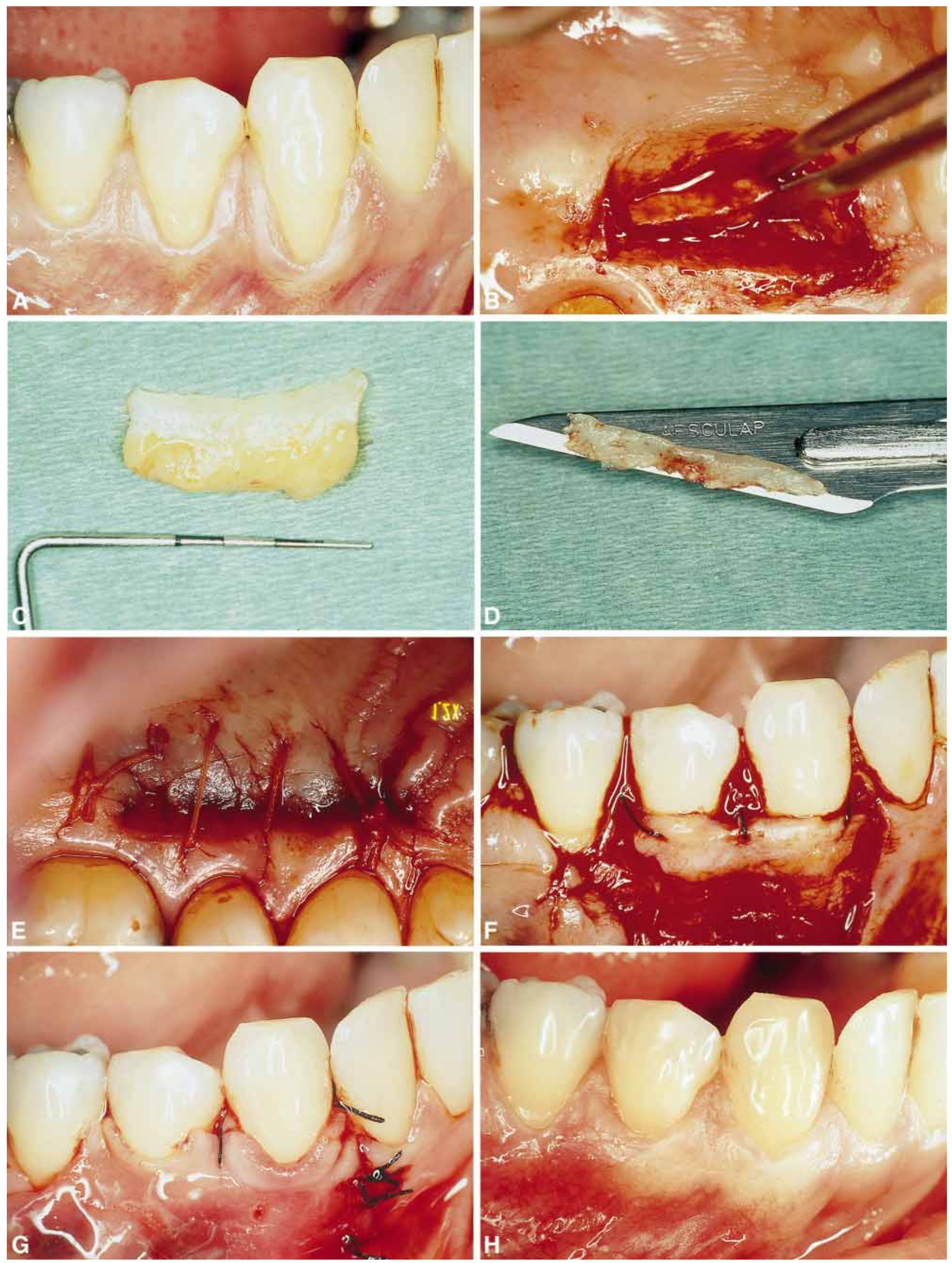

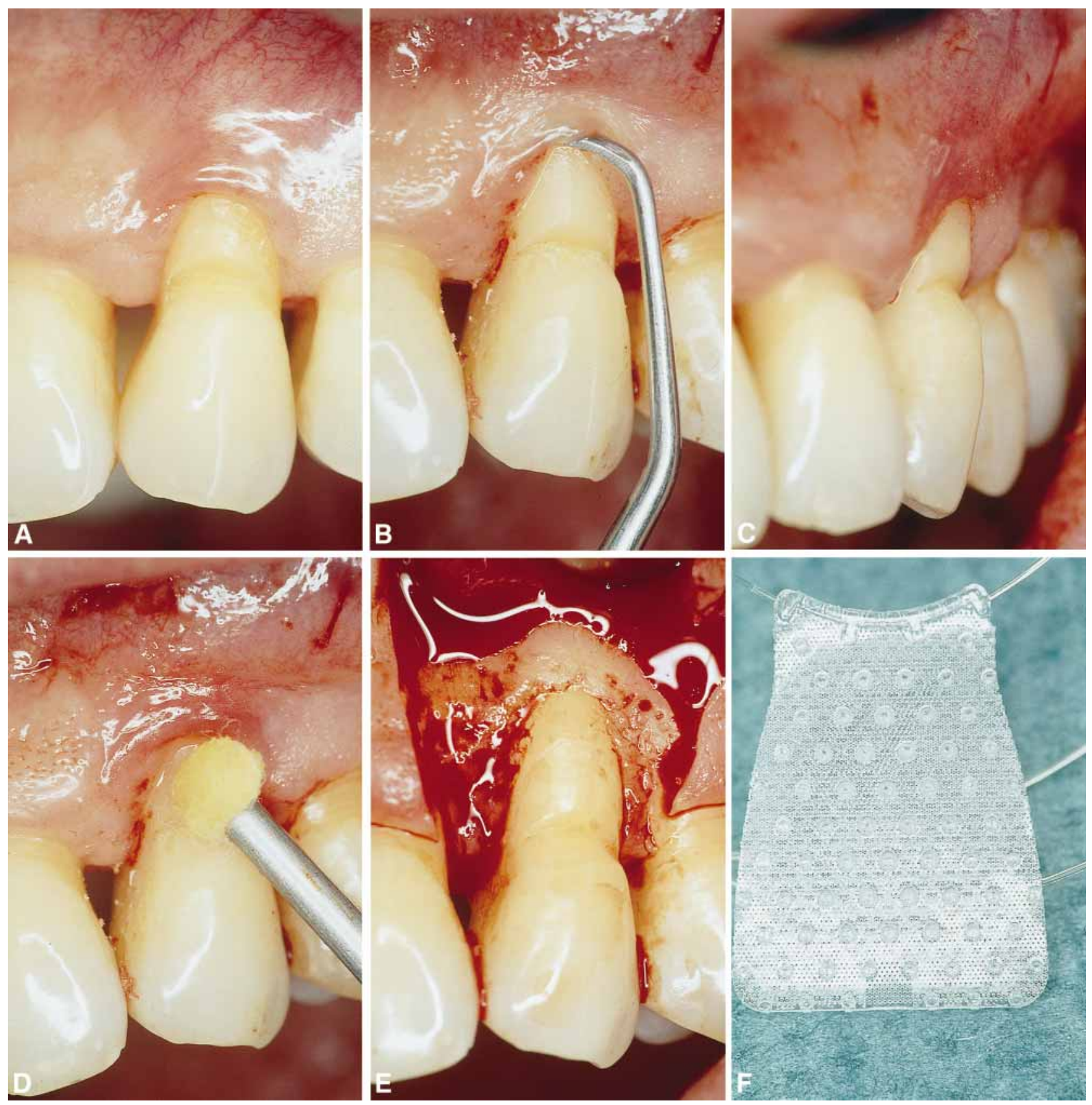

a central vertical linear measurement taken in mm in the area of recession. This measurement cannot fully estimate the aesthetic success of the procedure because of two reasons: (1) a single measurement does not accurately reflect the shape and the area of residual recession; (2) the visual aspect of the graft and surrounding tissues is not taken into account.

Thus, success criteria should not only be based upon the amount of root coverage but also upon the cosmetic integration of the operated zone within the mouth. Attention needs to be payed to additional factors (Fig. 16). In a comparative study on root coverage, we attempted to evaluate aesthetic results (19). Impressions and photographs of the recessions were made preoperatively and 6 months later. Each photograph was magnified on a screen. The photographs and the impressions were examined and compared by two independent examiners who were blind to the given treatment. The evaluation of the aesthetic results was scored using a three-step scale: good, moderate or poor. Concordance between examiners was assessed by a kappa test. The examiners were asked to score an overall impression of the surrounding tissues, not just the amount of root 

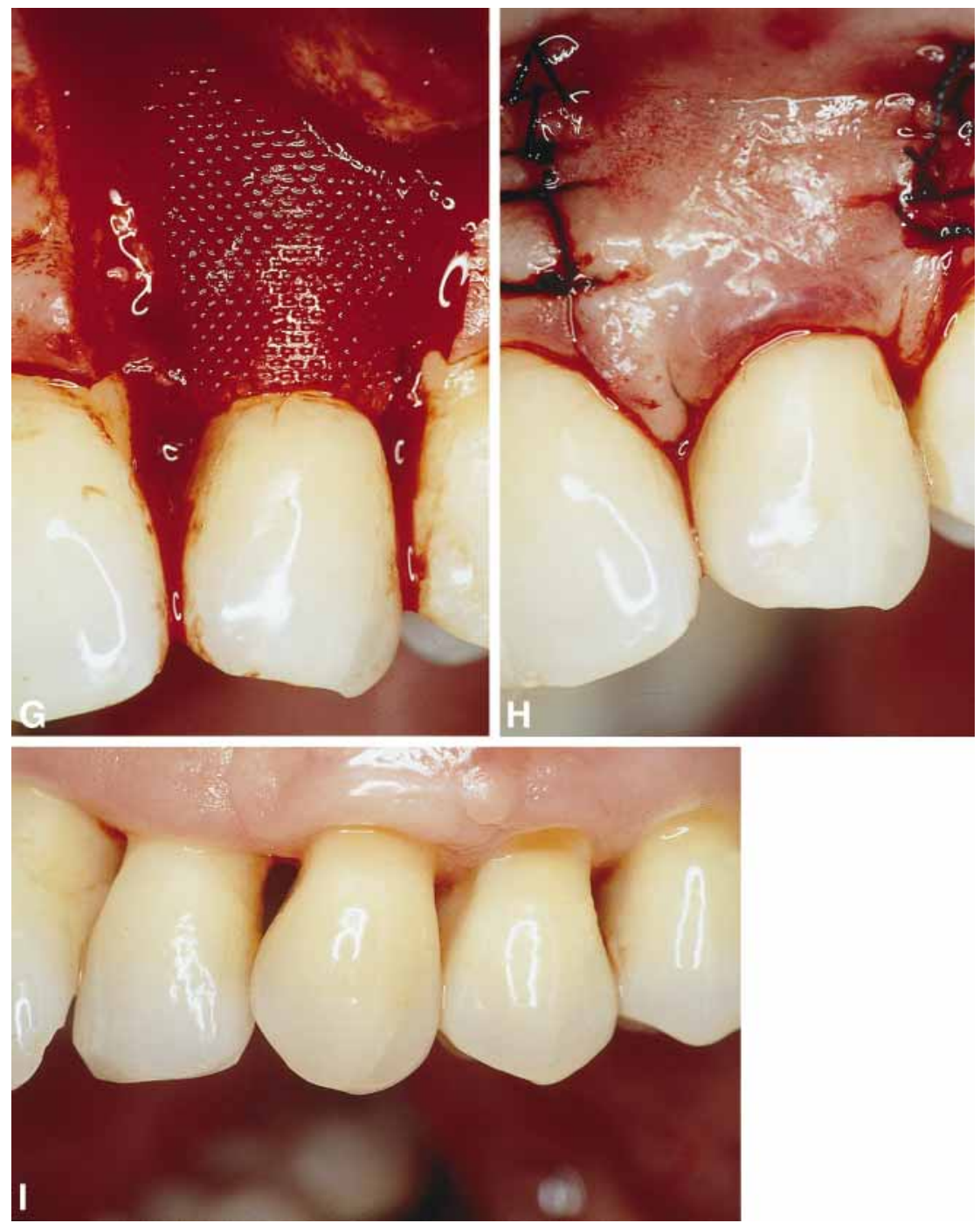

Fig. 15. A. Moderate-wide recession defect on a maxillary canine (Miller Class III). B. The cervical abrasion may create adequate space for ingrowth of periodontal ligament tissue. C. A guided tissue regeneration technique is chosen using a biodegradable membrane barrier (Guidor ${ }^{\circledR}$ ). D. The root surface is gently planed. E. The defect area is con-

surface that was covered. Table 5 indicates the four relevant factors taken into account by the panel of examiners to score a global aesthetic impression. Hopefully, a system like this, one and the same and universally used, can soon be agreed upon and regularly included in clinical studies.

\section{Decision-making}

\section{Patient evaluation}

\section{Patient psychology}

In 1987, the definition of cosmetic surgery of the American Society of Plastic and Reconstructive Sur- ditioned with a solution of $50 \mathrm{mg} / \mathrm{ml}$ tetracycline HCL for 5 minutes. F. Two vertical releasing incisions are made. G. The membrane is secured up to the cementoenmal junction. H. The flap is sutured over the membrane. I. Thirty months post-surgery. Root coverage is limited to the height of contour of the interproximal tissue.
Table 5. Professional evaluation factors for aesthetic outcome of root coverage procedures

\begin{tabular}{l}
\hline Degree of root coverage \\
\hline Color match of the tissues \\
Alveolar mucosa \\
Pre-existing keratinized tissues \\
Gingival graft \\
\hline Soft tissue appearance \\
Lack of hypertrophic scars or fibrosis \\
Matching volume and texture \\
\hline Location of the mucogingival line \\
\hline
\end{tabular}




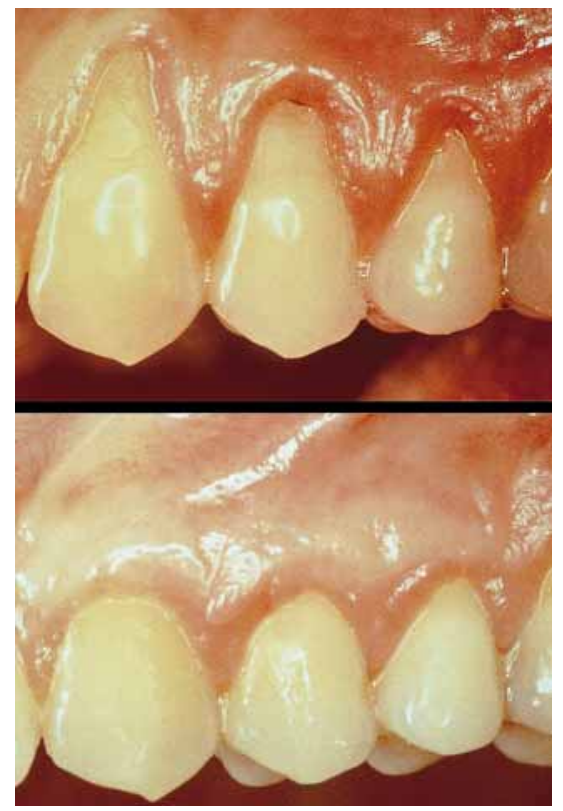

Fig. 16. Top. Episodes of necrotizing gingivitis resulting in recession defects on the canine, first and second bicuspid. Bottom. 2 years post-treatment following submerged graft. Patient's expectation matches surgeon's ability. Both are satisfied with the results. Aesthetic criteria of success are fulfilled.

geons, accepted by the American Medical Association in June 1989, was the following: "Cosmetic surgery is performed to reshape normal structures of the body in order to improve the patient's appearance and self-esteem". Thus, the end goal of aesthetic surgery is "to boost self-esteem" (37). This means that aesthetic procedures deal with psychoanalytic and social behavior.

Gingival recession is often a source of anxiety to patients. So far, no psychological instrument in the field of aesthetic dentistry has been developed to identify the patient profile. Nevertheless, information collected during the consultation can reveal a psychological profile that may jeopardize patient satisfaction.

- Noncompliant patients should be considered at risk. Compliance is needed for success of root coverage. Long-term, the patient has to modify his or her hygiene habits in order to avoid marginal inflammation and minimize toothbrushing trauma (31) (Fig. 17). Success decreases with poor plaque control (25). Short-term, the fragile interface between the root surface and the soft tissues during the days following the operation requires strict compliance with postoperative instructions.

- Gingival recessions can be the visible sign of on- going periodontitis. If so, the periodontal disease must be first treated. Usually, patients with ongoing periodontitis seeking for aesthetic concerns are not good candidates for root coverage procedures (34). There is a discrepancy between aesthetic expectation and the likelihood of further gingival recession as part of the periodontal healing process.

- An unsatisfied patient already subjected to multiple aesthetic procedures should be suspected of never being satisfied. The demand for repeated surgery can be, in fact, a sign of psychopathology (polysurgical addiction).

- Patients presenting factitious gingival ulceration should be carefully evaluated prior to root coverage procedures. Self-inflicted periodontal injuries can be related to mental disorders (92) such as Munchausen's syndrome (51) or dysmorphophobia. Based on information from the American Psychiatric Association (6), when this behavior persists for 4 weeks or longer, it may refer to mental

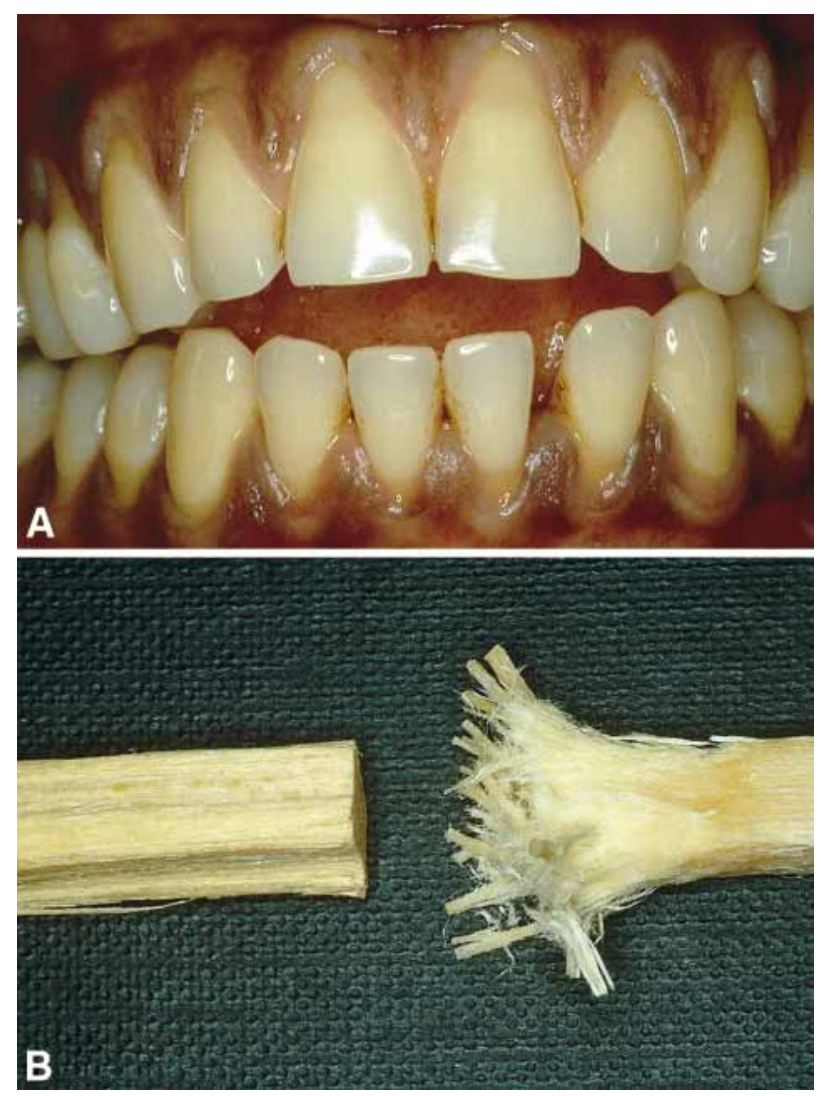

Fig. 17. A. Multiple Class II recessions associated with mechanical trauma (29-year-old man from Togo). B. Piece of soft wood used by the patient as a toothbrush. Any surgical attempt aiming at covering the recessions will fail until oral hygiene habits are modified. 


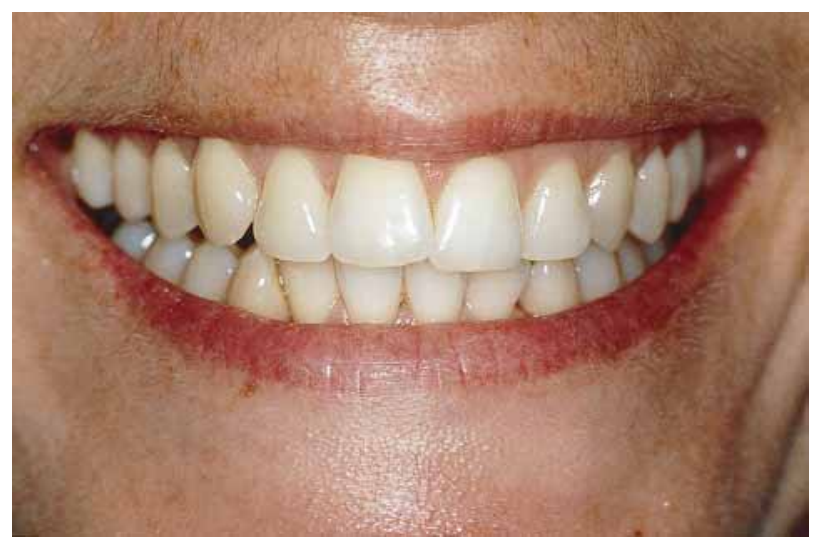

Fig. 18. In a social smile, most patient displays eight maxillary teeth. In full laugh, the exposure can extend to the mesial portion of the first maxillary molar.

disorders. It can be deducted that at least a 1month observation period is necessary prior to a decision to surgically correct factitial defects.

- The cosmetic zone, as experienced by the patient, may be not limited to the smile (Fig. 14). It depends on the patient's perception of his body. A firm request for aesthetic root coverage procedure in nonvisible areas should be discussed.

- Aesthetic demands for treatment of shallow Class I recessions should be carefully analyzed. Even if the percentage of complete root coverage is high in this defect category, the surgeon should keep in mind that the more aesthetic the demand, the more difficult it is to satisfy the patient.

\section{Risk factors}

Little is known about various characteristics of the patients relative to the results. Only one attempt seems to have been made (46) but, as has been suggested, the high degree of success of this study (89\% of complete root coverage) may explain that the patient characteristics evaluated were not related to the results (30). For example, there is no information about the influence of gender and age of the patients on the success rates.

A recent study suggests an association between smoking and gingival recession in subjects presenting minimal or no periodontal disease (41). However, evaluations of the impact of smoking on the outcome of root coverage procedures are contradictory. In two studies using free soft tissue graft, the results do not seem to be affected by tobacco consumption $(46,110)$. This is in contrast to one study using free connective tissue graft (71), and two studies using guided tissue regeneration techniques $(114,125)$; where smokers showed less root coverage. However, in view of the growing number of studies demonstrating a negative effect of tobacco consumption on periodontal wound healing $(30,105)$, it seems reasonable to consider smoking a risk factor.

The smile line also needs to be considered. Normally, the cosmetic zone is limited to the maxilla. The position of the lip line relative to the gingival line determines the amount of gingival exposure (65) (Fig. 18). Patients presenting a "gummy smile" should be carefully evaluated before root coverage procedures. The surgical challenge is great, because the smile will expose the entire operated zone. These patients may require orthodontics and orthognatic surgery to improve the lip line.
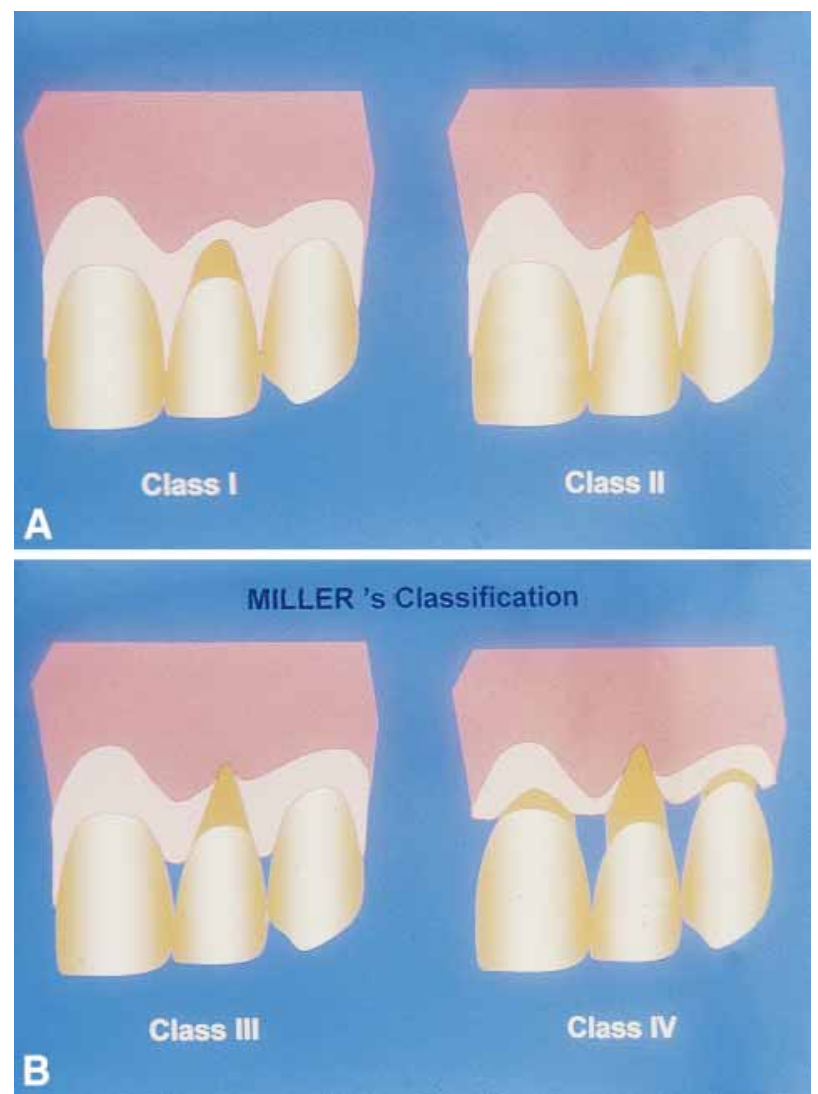

Fig. 19. Schematic drawing of Miller classification (68). A. Class I: Marginal tissue recession does not extend to the mucogingival junction. No loss of interdental bone or soft tissue. Class II: Marginal tissue recession extends to or beyond the mucogingival junction. No loss of interdental bone or soft tissue. B. Class III: Marginal tissue recession extends to or beyond the mucogingival junction. Loss of interdental bone or soft tissue is apical to the cementoenamel junction, but coronal to the apical extent of the marginal tissue recession. Class IV: Marginal tissue recession extends beyond the mucogingival junction. Loss of interdental bone extends to a level apical to the extent of the marginal tissue recession. 


\section{Defect evaluation}

So far, only case reports indicate that the loss of interdental papillae may be partially resolved in isolated defects by grafting procedures $(8,44)$. The lack of hard tissue support jeopardizes any attempt to fill the interproximal area. Thus, the commonly used Miller's classification (68) remains a convenient tool for prognosis evaluation (Fig. 19) (Table 6). However, this classification has some limitations.

- The position of the tooth and the alveolar ridge are not taken into account. Recessions in teeth in a labial position may require orthodontic treatment prior to surgical procedures.

- The size of the defect in both vertical and horizontal dimensions must be considered. As a rule of thumb, the literature classifies the defects as shallow $(<3 \mathrm{~mm})$, moderate ( 3 to $5 \mathrm{~mm}$ ) or deep ( $>5$ $\mathrm{mm})$. On average, clinical studies indicate a defect width of $4.5 \mathrm{~mm}$. A $5-\mathrm{mm}$ width should be viewed as wide. It is to be assumed that the larger the recession area, the less root coverage should be expected.

- The residual depth of the vestibule also seems to be of importance for the selection of procedures.

\section{Choice of technique}

In periodontal plastic surgery, the choice of procedure is based on the four cardinal principles of any surgery: success, reproducibility, lack of morbidity and economy. Basically, the easier the technique the more reproducible it is, since the need for technical skill of the surgeon is reduced. A skillfully performed operation is $75 \%$ decision-

Table 6. Prognosis for root coverage related to defect morphology

Class I and II
Initial recession depth $<5 \mathrm{~mm}$
Favorable prognosis: complete root coverage can be
achieved.
Initial recession depth $\geq 5 \mathrm{~mm}$
Uncertain prognosis: limited number of teeth will show
complete root coverage.
Class III
Poor prognosis: no tooth will present complete root
coverage.
Class IV
No root coverage can be anticipated.

\section{Class I and II}

Initial recession depth $<5 \mathrm{~mm}$

achieved.

Initial recession depth $\geq 5 \mathrm{~mm}$ complete root coverage.

Class III

Poor prognosis: no tooth will present complete roo

Class IV

No root coverage can be anticipated making and $25 \%$ dexterity (27). Cosmetic surgery remains highly dependent on the skill of the operator, and technological advances should be viewed with this in mind (53). Sophisticated procedures may lead to postsurgical complications that can impair aesthetic outcomes. Time-consumption and increased fees are also factors to consider in the selection of procedure. In fact, both are linked. This implies the choice of a single-step procedure without additive treatments, which increase duration and cost of the operation. In coverage of exposed roots, a questionnaire has revealed singlestep surgery to be the patient's choice (89).

The description of the subepithelial connective tissue graft technique by Langer \& Langer in 1985 represents a breakthrough in the coverage of exposed root surfaces (60). Submerged grafts are now the reference for prospective comparative studies on the use of various root coverage techniques (Table 7).

The surgeon's choice will be based on the confidence he has of his own ability to match the outcomes of the clinical trials. Table 1 and 2 summarize data from clinical studies on the effect of various root coverage procedures. The results of nonsubmerged grafts are not included since they have been extensively reviewed previously $(30,117,119)$. Due to differences between protocols, these tables must be carefully interpreted. Nevertheless, the mean percentages express a trend, which can be taken into account by the clinician.

Interestingly, wide ranges of results are observed for submerged grafts as well as for the other techniques. These variations suggest limited reproducibility of procedures that require high surgical skills. They confirm the clinical opinion that these techniques are operator-sensitive.

\section{Dated procedures}

Nonsubmerged grafts are no longer justified in the coverage of recession defects for aesthetic purposes. The procedure is uncomfortable for the patient because of the denuded palatal donor site, and the match with the surrounding tissues is unpredictable.

The double papilla flap also seems to be a dated technique. Use of elaborate sutures is time-consuming. The procedure requires surgeon's dexterity. Sutures placed over the avascular root surface may lead to postoperative cleft complications that may impair esthetic results. Similarly, there seems to be little clinical advantage in using double pedicle flap to cover connective tissue grafts. 





Table 8. Decision-aid model for root coverage surgery (Class I and II defects)

\begin{tabular}{|c|c|c|c|c|c|c|}
\hline \multirow{3}{*}{$\begin{array}{l}\text { Defect size } \\
(\mathrm{mm})\end{array}$} & \multicolumn{3}{|c|}{ Shallow residual vestibule depth } & \multicolumn{3}{|c|}{ Deep residual vestibule depth } \\
\hline & \multicolumn{2}{|c|}{ No gingival augmentation } & Gingival augmentation & \multicolumn{2}{|c|}{ No gingival augmentation } & Gingival augmentation \\
\hline & Narrow $\leq 5$ & Wide $>5$ & Narrow $\leq 5 \quad$ Wide $>5$ & Narrow $\leq 5$ & Wide $>5$ & Narrow $\leq 5 \quad$ Wide $>5$ \\
\hline Shallow $<3$ & \multicolumn{5}{|c|}{ Semilunar flap or coronally positioned flap } & $\begin{array}{l}\text { Connective tissue graft } \\
+ \text { envelope }^{*}\end{array}$ \\
\hline Moderate $3-5$ & \multicolumn{3}{|c|}{ Connective tissue graft + envelope ${ }^{*}$} & $\begin{array}{l}\text { Coronally } \\
\text { positioned } \\
\text { flap }\end{array}$ & $\begin{array}{l}\text { Connective } \\
\text { tissue graft }+ \\
\text { coronally po- } \\
\text { sitioned } \\
\text { flap** }\end{array}$ & $\begin{array}{l}\text { Connective tissue graft } \\
+ \text { coronally positioned } \\
\text { flap }\end{array}$ \\
\hline Deep $>5$ & \multicolumn{3}{|c|}{ Connective tissue graft + envelope* } & \multicolumn{2}{|c|}{$\begin{array}{l}\text { Connective tissue graft }+ \\
\text { coronally positioned flap }\end{array}$} & $\begin{array}{l}\text { Connective tissue graft } \\
+ \text { envelope }\end{array}$ \\
\hline
\end{tabular}

Table 9. Mean increase in gingival height in $\mathrm{mm}$ in Class I and Class II defects: summary of data from comparative and non-controlled case studies. Selection criteria: 6-month minimum follow-up, at least 10 patients per group, initial recession depth data available

\begin{tabular}{|c|c|c|c|c|c|c|}
\hline Procedure & $\begin{array}{l}\text { Number } \\
\text { of selected } \\
\text { studies }\end{array}$ & $\begin{array}{l}\text { Number } \\
\text { of study } \\
\text { groups }\end{array}$ & $\begin{array}{l}\text { Number } \\
\text { of patients }\end{array}$ & $\begin{array}{l}\text { Number } \\
\text { of teeth }\end{array}$ & $\begin{array}{l}\text { Maximum } \\
\text { length of } \\
\text { studies in } \\
\text { months }\end{array}$ & $\begin{array}{l}\text { Mean increase } \\
\text { in height } \\
\text { (range) }\end{array}$ \\
\hline Rotational flaps $^{a}$ & 5 & 7 & 107 & 113 & 9 & $3.16(2.7-4.0)$ \\
\hline Advanced flaps ${ }^{\mathrm{b}}$ & 4 & 5 & 72 & 152 & 96 & $0.4(-0.4-1.3)$ \\
\hline $\begin{array}{l}\text { Submerged grafts } \\
\text { +rotational flaps }{ }^{\mathrm{c}} \\
\text { Coronally positioned flap }^{\mathrm{d}} \\
\text { Envelope }^{\mathrm{e}}\end{array}$ & $\begin{array}{l}5 \\
9 \\
4\end{array}$ & $\begin{array}{r}5 \\
11 \\
4\end{array}$ & $\begin{array}{r}137 \\
224 \\
50\end{array}$ & $\begin{array}{r}170 \\
248 \\
64\end{array}$ & $\begin{array}{l}18 \\
60 \\
48\end{array}$ & $\begin{array}{l}2.8(2.1-3.3) \\
1.8(0.6-3.1) \\
2.4(1.2-3.5)\end{array}$ \\
\hline $\begin{array}{l}\text { Guided tissue regeneration } \\
\text { Nonresorbable membrane }{ }^{f} \\
\text { Resorbable membrane }^{\mathrm{g}}\end{array}$ & $\begin{array}{l}\text { chniques } \\
9 \\
7\end{array}$ & $\begin{array}{l}9 \\
8 \\
\end{array}$ & $\begin{array}{r}145 \\
98 \\
\end{array}$ & $\begin{array}{l}145 \\
104 \\
\end{array}$ & $\begin{array}{l}48 \\
12 \\
\end{array}$ & $\begin{array}{l}0.9(0.0-1.9) \\
0.5(-0.4-2.0)\end{array}$ \\
\hline $\begin{array}{l}\text { Selected studies: } \\
\text { a 25, 33, 40, 98, 123. } \\
\text { b } 67,91,113,118 . \\
\text { c } 15,16,46,48,88 . \\
\text { d } 16,17,19,20,49,78,116,118,125 . \\
\text { e } 4,58,72,86 . \\
\text { f } 58,83,89,90,107,109,111,112,125 \\
\text { g } 17,48,49,63,89,116,125 .\end{array}$ & & & & & & \\
\hline
\end{tabular}

\section{Current procedures}

\section{Decision-aid model for soft tissue grafts}

It is our opinion that the operator's choice in clinical practice could be limited to use of pedicle soft tissue grafts and submerged connective tissue grafts. The application of these two techniques should be based upon various aspects of the anatomy of the individual defect site. In Table 8 we propose a decision-aid model that considers the size of the defect to be treated, the need for gingival augmentation, and the residual depth of the vestibule in a effort to achieve best possible overall aesthetic result.

\section{Size of the defect}

The semilunar flap, easy to perform, is highly reproducible in shallow recession defects when gingival augmentation is not needed. In Class I moderate defects, similar degrees of root coverage have been reported with coronally positioned flap and submerged graft. Nevertheless, less favorable results were observed in defects presenting an initial recession depth $\geq 5 \mathrm{~mm}$ (118). With reference to the healing events described above, it is reasonable to assume that moderate recessions should be treated with coronally positioned flaps, whereas submerged 


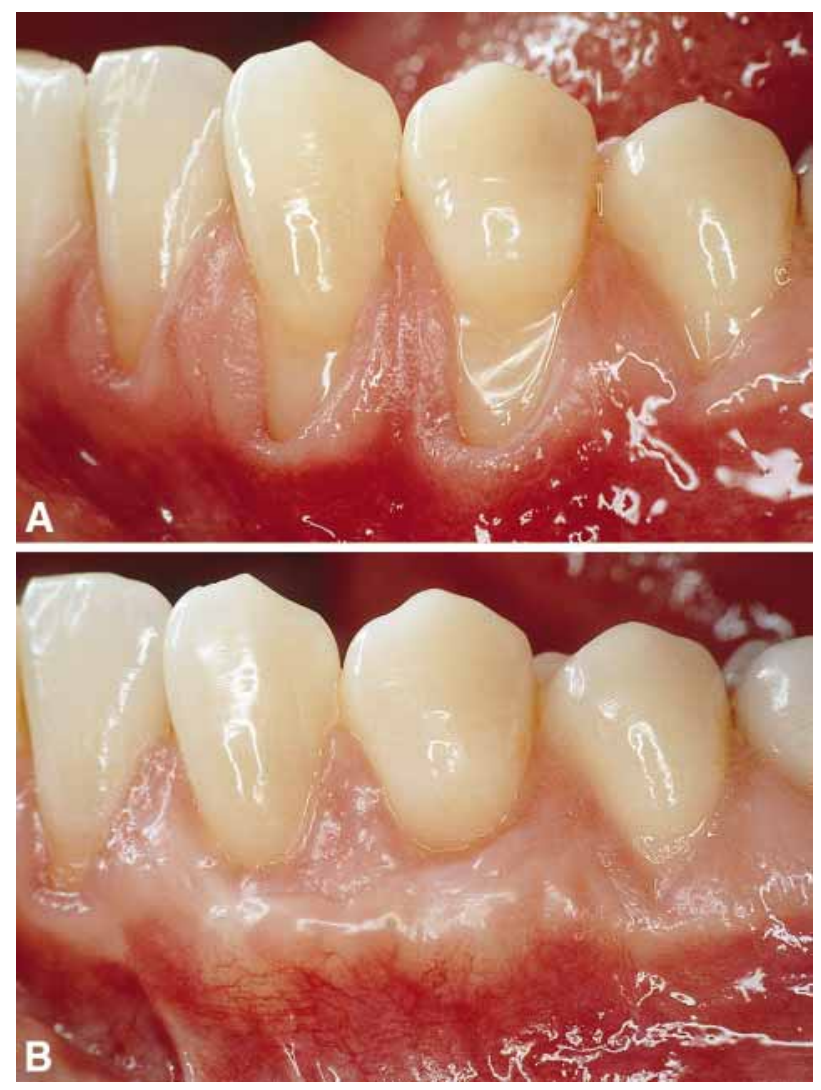

Fig. 20. A. A mandibular canine and a premolar with deep recession defects and extensive abrasion. B. 1 year posttreatment following subepithelial connective tissue graft. Complete root coverage is achieved. However, the aesthetic evaluation is classified as moderate due to the soft tissue appearance. A gingival groove marks the border of the epithelial band of the graft, which was left coronal to the flap margin.

graft procedures seem to be needed for wide and/or deep defects.

Envelope procedures without vertical releasing incisions should be preferred over other techniques as they prevent any unappealing postoperative scar lines. Tunnel approach allows multiple recessions to be treated in one session. At the donor site, a long wedge of tissue must be pulled out. To avoid the risk of cyst formation, the epithelium of the graft to be covered by the interdental gingiva must be carefully excised.

\section{Need for gingival augmentation}

Some increase in gingival height is found following all root coverage procedures (Table 9). However, rotational flaps and submerged grafts provide more increase than advanced flaps and membrane techniques. Connective tissue grafts combined with co- ronally positioned flap show somewhat lower increase in gingival height than envelope procedures.

When partially submerged grafts are used, a gingival groove is often formed between the coronal border of the flap and the epithelial band of the graft (Fig. 20). This tends to affect the aesthetic result. Histologically, deep epithelial projections are found at the junction between the gingival flap and the transplanted connective tissue (76) (Fig. 21). Thus, when increased gingival height is not required, the epithelial collar of the connective tissue should be excised, and the graft completely covered by the flap. However, a "surgical cyst" has been reported 15 months post-surgery following this technique (22). Care must be taken to completely remove the epithelial collar of the graft. Hurtzeler \& Weng have described a surgical approach at the donor site, which does not include harvesting the epithelial border of the graft (55) (Fig. 22).

Increased gingival thickness is observed with submerged connective tissue grafts (49) and can possibly be doubled (71). An increase in gingival thickness may be advantageous at sites with subgingival restorations (119). Deep cervical abrasions should also be considered. Connective tissue grafts may be best suited to avoid the collapse of the flap onto the

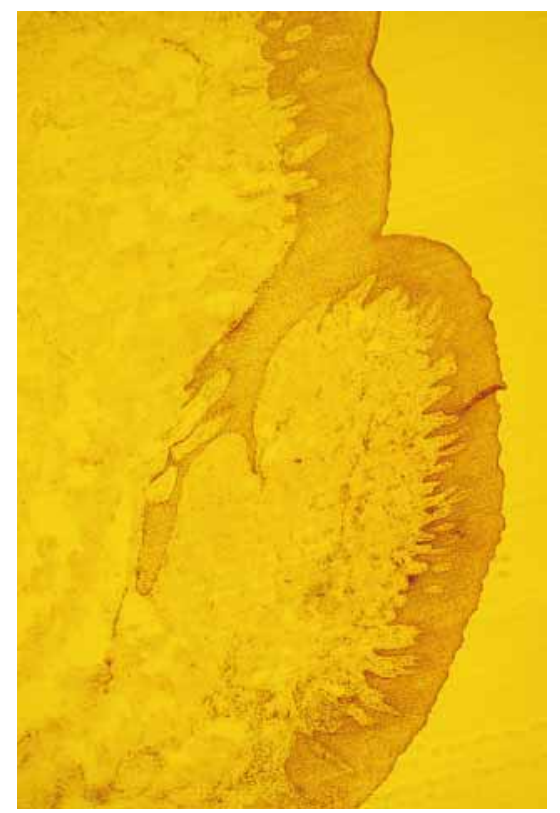

Fig. 21. Twelve-month biopsy of a subepithelial connective tissue graft. A long epithelial projection into the connective tissue marks the border between the flap (bottom) and the graft (top). Hematoxylin and eosin. Original magnification $\times 110$. Laboratoire de Recherche UPRES-A 7052 CNRS. 


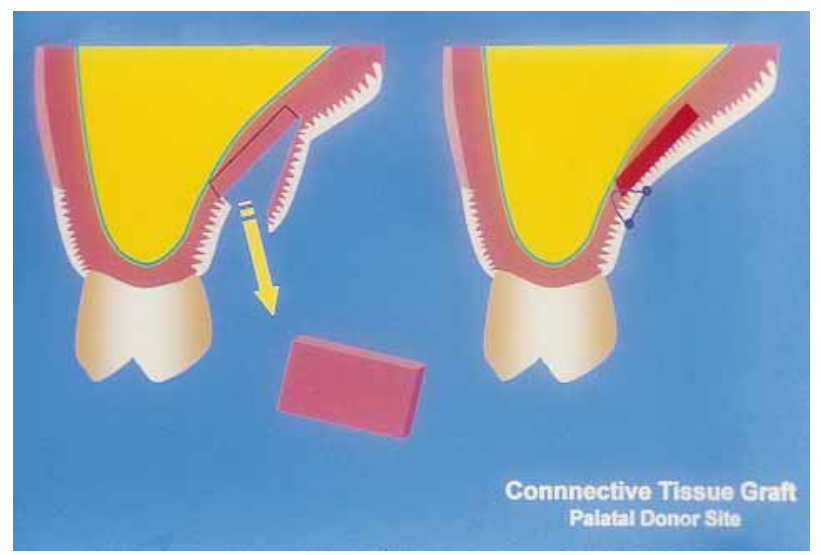

Fig. 22. Schematic drawing illustrating the surgical procedure at the donor site. In this case, the graft is removed without the epithelial collar.

root surface, and to provide better restoration of the soft tissue morphology.

Laterally positioned flaps can be proposed to increase the gingival height for root coverage of isolated recessions when neighbouring gingiva is sufficient. In situations where an increase of gingival height and thickness is desirable, submerged grafts are preferred $(49,125)$.

\section{Residual depth of the vestibule}

The distance between the base of the recession and the bottom of the vestibule has not yet been debated in the literature. Excessive coronal positioning of the mucogingival line as a consequence of coronally positioned flap may, in a shallow residual depth, impair the aesthetic results, even if long-term studies indicate that the mucogingival line tends to regain its initial position over time $(1,83)$. Furthermore, coronal traction of the covering soft tissues may disrupt the wound during the healing phase. Submerged grafts without coronal positioning, as described by Raetzke (86), are to be preferred. This envelope technique gives less traction and provides increased gingival height (Fig. 23).

\section{Additive treatments}

From an aesthetic viewpoint, the histological outcome of root coverage techniques might appear to be of little importance. However, lack of bone support is a major risk factor in the causation of gingival recession. Thus, regenerative techniques aimed at restoring a new functional attachment apparatus with formation of cementum, periodontal ligament and alveolar bone seem advantageous, even if this possibility has not as yet been demonstrated in humans.

\section{Root surface modification agents}

Animal and clinical studies have failed to demonstrate that root surface modification agents improve the mean percentage of root coverage $(5,30)$. However, recent clinical studies still use root surface conditioning $(20,48,49,58,72,116)$. As demonstrated by our compilation of data, few prospective comparative studies have explored the clinical effect of decalcifying agents (Table 10). The lack of difference between groups can also be interpreted as an inability of root surface modification agents to induce a clinical effect, which would reach statistical significance. However, the use of citric acid or tetracycline hydrochloride may be justified as a means to remove the instrumentation smear layer.

\section{Enamel matrix proteins}

Histological findings indicate that the application of enamel matrix proteins in treatment of recessiontype defects may result in the formation of a new attachment apparatus $(43,94)$. A 6 -month case series indicates mean recession coverage of $81 \%$ following the use of enamel matrix proteins in conjunction with a coronally positioned flap (52). These results need to be confirmed by further studies.

\section{Guided tissue regeneration}

It appears that resorbable membranes should be used for guided tissue regeneration, since the clinical outcome is similar to that following nonresorbable membranes (Table 1), and a second surgical procedure for membrane removal is not needed.

However, over the years it has become our impression that it is questionable whether membrane techniques offer any benefits over submerged grafts, which overall seem more preferable and can be used in all situations considered for membrane methods. A number of reasons can be advocated.

- The mean percentages of root coverage and teeth with complete root coverage indicate more favorable results with submerged graft techniques (Tables 1, 2).

- When membranes are used, infection risk during the healing period is high (97). Adverse side effects as foreign body reaction have recently been 

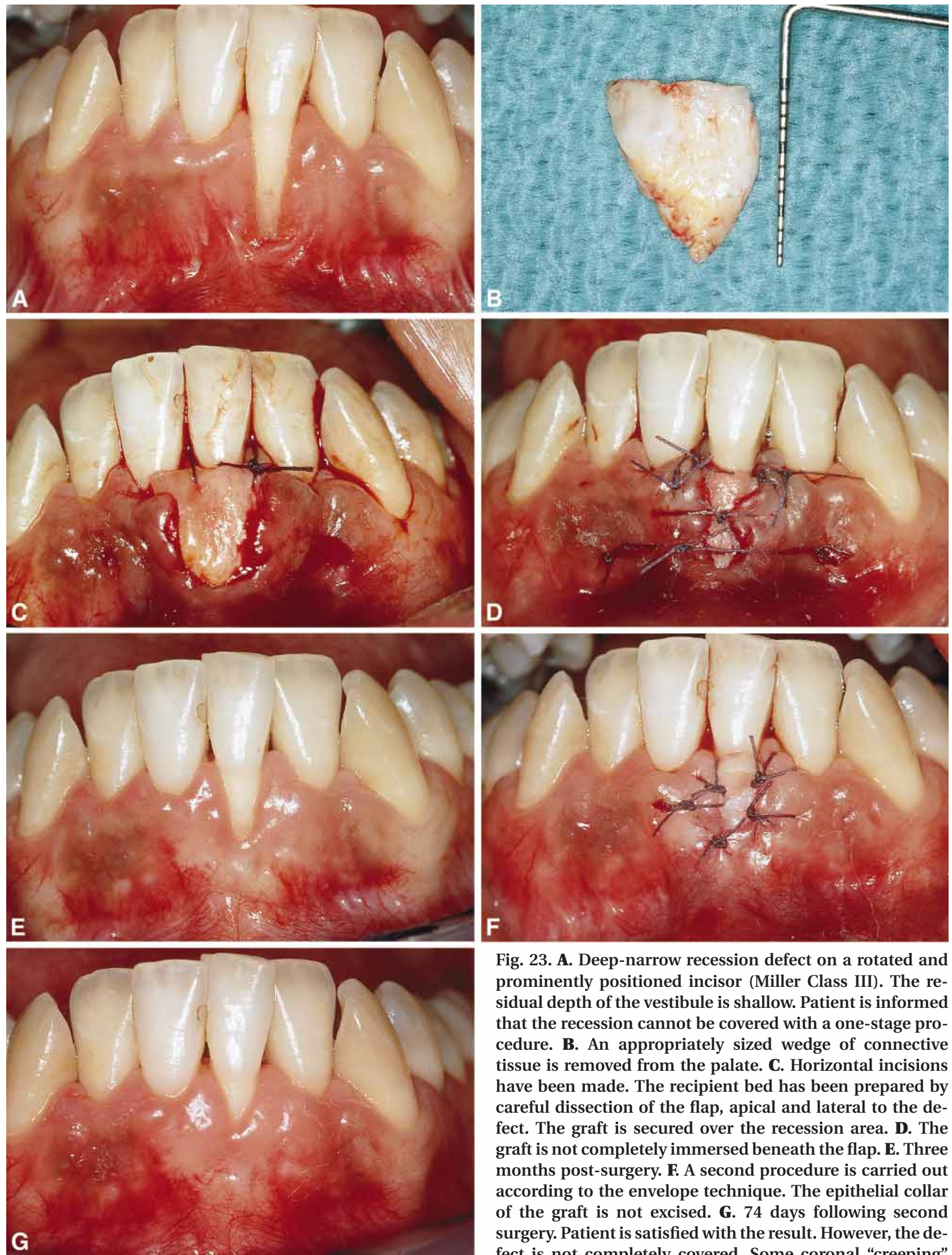

Fig. 23. A. Deep-narrow recession defect on a rotated and prominently positioned incisor (Miller Class III). The residual depth of the vestibule is shallow. Patient is informed that the recession cannot be covered with a one-stage procedure. B. An appropriately sized wedge of connective tissue is removed from the palate. C. Horizontal incisions have been made. The recipient bed has been prepared by careful dissection of the flap, apical and lateral to the defect. The graft is secured over the recession area. D. The graft is not completely immersed beneath the flap. E. Three months post-surgery. F. A second procedure is carried out according to the envelope technique. The epithelial collar of the graft is not excised. G. 74 days following second surgery. Patient is satisfied with the result. However, the defect is not completely covered. Some coronal "creeping" may be expected over time. This case illustrates the difficulty in fulfilling professional evaluation factors for aesthetic outcome in deep Class III recession defects. 




reported (103). Frequent postoperative examinations and antibiotic regimens increase patient discomfort.

- Complications, when they occur, are more difficult to correct following guided tissue regeneration. The bioabsorption process of the material during the healing phase makes it impossible to remove resorbable membranes. Consequently, postoperative infections mostly turn into dramatic aesthetic outcomes, leading to additional corrective procedures.

- Membrane techniques appear to be sensitive to the thickness of the covering tissues. The mean residual recession has been found to be three times higher when nonresorbable membranes are used in a thin soft tissue area $(\leq=1 \mathrm{~mm})$ than when tissues are thick (7). A significant difference between the use of absorbable membrane and connective tissue grafts has been reported in mean root coverage whith thin overlying tissues: $26.7 \%$ and $95.9 \%$, respectively (48).

- Submerged graft may allow lower fees.

Long-term follow-ups after submerged grafts and other nonmembrane procedures show stability of initial results $(66,78,83,91)$. We feel that this circumstance, together with the lack of data to demonstrate enhanced new attachment following guided tissue regeneration, provide no preference for membrane techniques. Thus, from a clinical perspective, even if tissue match following guided tissue regeneration is good, nonmembrane techniques are our preference for root coverage in aesthetics. Nevertheless, the possibility of enhanced formation of new bone following use of membranes should be kept in mind.

\section{Concluding remarks}

This chapter has emphasized that, in aesthetics, the selection of surgical techniques for root coverage should not only consider the results evaluated by millimeter and percentage data. Clinical trials should include methods for patient's own evaluation as well as professional evaluation of the overall aesthetic outcome.

In decision-making, evaluation of general patient characteristics and evaluation of various aspects of the anatomy at the individual defect site need to be considered.

New procedures should be developed to improve complete root coverage in Class I and Class II re- 
cession defects. They should be simplified to ensure a wider reproducibility and to decrease the costbenefit ratio. Progress in the creation of gingival papillae in Class III and Class IV recession defects is desirable.

Further research is needed to evaluate the influence of soft and hard tissue attachment to the root on the stability of the results.

\section{References}

1. Ainamo A, Bergenholtz A, Hugoson A, Ainamo J. Location of the muco-gingival junction 18 years after apically repositioned flap surgery. J Clin Periodontol 1982: 19: 49-52.

2. Allen EP, Miller PD. Coronal positioning of existing gingiva: short term results in the treatment of shallow marginal tissue recession. J Periodontol 1989: 60: 316-319.

3. Allen AL. Use of the supraperiosteal envelope in soft tissue grafting for root coverage. I. Rationale and technique. Int J Periodontics Restorative Dent 1994: 14: 216-227.

4. Allen AL. Use of the supraperiosteal envelope in soft tissue grafting for root coverage. II. Clinical results. Int J Periodontics Restorative Dent 1994: 14: 302-315.

5. American Academy of Periodontology. Consensus report. Mucogingival therapy. Ann Periodontol 1996: 1: 705.

6. American Psychiatric Association. Diagnostic and statistical manual of mental disorders. 4th edn. Washington, DC: APA, 1994: 466-469.

7. Anderegg CR, Metzler DG, Nicoll BK. Gingiva thickness in guided tissue regeneration and associated recession at facial furcation defects. J Periodontol 1995: 66: 397-402.

8. Azzi R, Etienne D, Carranza F. Surgical reconstruction of the interdental papilla. Int J Periodontics Restorative Dent 1998: 18: 466-473.

9. Bahat O, Handelsman M, Gordon J. The transpositional flap in mucogingival surgery. Int J Periodontics Restorative Dent 1990: 10: 473-482.

10. Baldi C, Pini Prato GP, Pagliaro U, Nieri M, Saletta D, Muzzi L, Cortellini P. Coronally advanced flap procedure for root coverage. Is flap thickness a relevant predictor to achieve root coverage? A 19-case series. J Periodontol 1999: 70: 1077-1084.

11. Bartold PM, Narayanan AS. Biology of the periodontal connective tissues. Carol Stream, IL: Quintessence, 1998: 62.

12. Bernimoulin JP, Lÿschezr B, Mühlemann HR. Coronally repositioned periodontal flap. Clinical evaluation after one year. J Clin Periodontol 1975: 2: 1-13.

13. Bertrand PM, Dunlap RM. Coverage of deep wide gingival clefts with free gingival autografts: root planing with and without citric acid demineralization. Int J Periodontics Restorative Dent 1988: 8: 65-77.

14. Borghetti A, Gardella JP. Thick gingival autograft for the coverage of gingival recession: a clinical evaluation. Int J Periodontics Restorative Dent 1990: 10: 216-229.

15. Borghetti A, Louise F. Controlled clinical evaluation of the subpedicle connective tissue graft for the coverage of gingival recession. J Periodontol 1994: 65: 1107-1112.

16. Borghetti A, Durand B, Louise F. La greffe conjonctive dans le recouvrement des récessions gingivales. Evaluation de deux techniques. J Parondontol Implantol 1997: 16: 369379.

17. Borghetti A, Glise JM, Monnet-Corti V, Dejou J. Comparative clinical study of a bioabsorbable membrane and subepithelial connective tissue graft in the treatment of human gingival recession. J Periodontol 1999: 70: 123-130.

18. Bouchard P, Etienne D. La cicatrisation parodontale. J Parodontol Implantol 1993: 12: 227-236.

19. Bouchard P, Etienne D, Ouhayoun JP, Nilvéus R. Subepithelial connective tissue grafts in the treatment of gingival recessions. A comparative study of two procedures. J Periodontol 1994: 65: 929-936.

20. Bouchard P, Nilvéus R, Etienne D. Clinical evaluation of tetracycline $\mathrm{HCl}$ conditioning in the treatment of gingival recessions. A comparative study. J Periodontol 1997: 68: 262269.

21. Bourne GH. Nutrition and wound healing. In: Glynn LE, ed. Tissue repair and regeneration. Amsterdam: Elsevier/ North Holland Biomedical Press, 1981: 212-241.

22. Breault LG, Bilman MA, Lewis D. Report of a gingival "surgical cyst" developing secondarily to a subepithelial connective tissue graft. J Periodontol 1997: 68: 392-395.

23. Bruno JF. Connective tissue graft technique assuring wide root coverage. Int J Periodontics Restorative Dent 1994: 14: 126-137.

24. Caffesse RG, Guinard EA. Treatment of localized gingival recession. IV. Results after three years. J Periodontol 1980: 510: $167-170$.

25. Caffesse RG, Alspach SR, Morrison EC, Burgett FG. Lateral sliding flaps with and without citric acid. Int J Periodontics Restorative Dent 1987: 7: 43-57.

26. Cohen D, Ross S. The double papillae flap in periodontal therapy. J Periodontol 1968: 39: 65-70.

27. Darzi A, Smith S, Taffinder N. Assessing operative skill. BMJ 1999: 318: 887-888.

28. DeSanctis M, Zucchelli G. Guided tissue regeneration with a resorbable barrier membrane (Vicryl) for the management of buccal recession: a case report. Int J Periodontics Restorative Dent 1996: 16: 435-441.

29. Egelberg J. Regeneration and repair of periodontal tissues. J Periodontal Res 1987: 22: 233-243.

30. Egelberg J. Periodontics. The scientific way. Synopses of clinical studies. 3rd edn. Malmö: OdontoScience, 1999: 562.

31. Egelberg J. Oral hygiene methods. The scientific way. Synopses of clinical studies. 3rd edn. Malmö: OdontoScience, 1999: 119.

32. Egelberg J. Current facts on periodontal therapy. Q\&A. 1st edn. Malmö: OdontoScience, 1999: 62.

33. Espinel MC, Caffesse RG. Comparison of the results obtained with the lateral positioned pedicle sliding flap-revised technique and the lateral sliding flap with a free gingival graft technique in the treatment of localized gingival recession. Int J Periodontics Restorative Dent 1981: 1: 3037.

34. Etienne D, Azzi R, de la Ruffinière S, Bouchard P. Esthétique et traitement des parodontites. Considérations sur la récession gingivale. J Parodontol Implantol 1995: 14: 153-167.

35. Genon P, Genon-Romagna C, Gottlow J. Traitement des récession gingivales par la régénération tissulaire guidée: barrière résorbable. J Parodontol Implantol 1994: 13: 289-296.

36. Genon-Romagna C, Genon P. Traitement cosmétique des récessions gingivales. Comparaison entre la greffe conjonctive enfouie et la régéneration tissulaire guidée. J Parodontol Implantol 1995: 14: 135-146. 
37. Gilman SL. Creating beauty to cure the soul. Durham: Duke University Press, 1998: 141.

38. Grupe J, Warren R. Repair of a gingival defect by a sliding flap operation. J Periodontol 1956: 27: 290-295.

39. Grupe J. Modified technique for the sliding flap operation. J Periodontol 1966: 37: 491-495.

40. Guinard EA, Caffesse RG. Treatment of localized gingival recessions. III. Comparison on results obtained with lateral sliding and coronally repositioned flaps. J Periodontol 1978: 49: 457-461.

41. Gunsolley JC, Quinn SM, Tew J, Goos CM, Brooks CN, Schenkein HA. The effect of smoking on individuals with minimal periodontal destruction. J Periodontol 1998: 69: 165-170.

42. Hammarström L. Enamel matrix, cementum development and regeneration. J Clin Periodontol 1997: 24: 658-668.

43. Hammarström L, Heijl L, Gestrelius S. Periodontal regeneration in a buccal dehiscence model in monkeys after application of enamel matrix proteins. J Clin Periodontol 1997: 24: 669-677.

44. Han TJ, Takei HH. Progress in gingival papilla reconstruction. Periodontol 2000 1996: 11: 65-68.

45. Harris RJ. The connective tissue and partial thickness double pedicle graft: a predictable method of obtaining root coverage. J Periodontol 1992: 63: 477-486.

46. Harris RJ. The connective tissue with partial thickness double pedicle graft: the results of 100 consecutivelytreated defects. J Periodontol 1994: 65: 448-461.

47. Harris RJ, Harris AW. The coronally positioned pedicle graft with inlaid margins: a predictable method of obtaining root coverage of shallow defects. Int J Periodontics Restorative Dent 1994: 14: 228-24.

48. Harris RJ. A comparative study of root coverage obtained with guided tissue regeneration utilizing a bioabsorbable membrane versus the connective tissue with partial-thickness double pedicle graft. J Periodontol 1997: 68: 779-790.

49. Harris RJ. A comparison of 2 root coverage techniques: guided tissue regeneration with bioabsorbable matrix style membrane versus a connective tissue graft combined with a coronally positioned pedicle graft without vertical incisions. Results of a series of consecutive cases. J Periodontol 1998: 69: 1426-1434.

50. Harvey PM. Surgical reconstruction of the gingiva. II. Procedures. N Z Dent J 1970: 66: 42-52.

51. Heasman PA, MacLeod I, Smith DG. Factitious gingival ulceration: a presenting sign of Munchausen's syndrome? J Periodontol 1994: 65: 442-447.

52. Heinz B, Jepsen K, Arjomand M, Jepsen S. Enamel matrix derivative in the treatment of periodontal recession defects. J Periodontol Acad Rep 1999: 70: 235-236.

53. Hoeyberghs JL. Cosmetic surgery. BMJ 1999: 318: 512-516.

54. Holbrook T, Ochsenbein C. Complete root coverage on the denuded root surace with a one-stage gingival graft. Int $\mathrm{J}$ Periodontics Restorative Dent 1983: 3: 9-27.

55. Hürzeler MB, Weng D. A single-incision technique to harvest subepithelial connective tissue grafts from the palate. Int J Periodontics Restorative Dent 1999: 19: 278-287.

56. Ibbott CG, Oles RD, Laverty WH. Effects of citric acid treatment on autogenous free graft coverage of localized recession. J Periodontol 1985: 56: 662-665.

57. Jahnke PV, Sandifer JB, Gher ME, Gray JL, Richardson AC. Thick free gingival and connective tissue autografts for root coverage. J Periodontol 1993: 64: 315-322.
58. Jepsen K, Heinz B, Halben J, Jepsen S. Treatment of gingival recession with titanium reinforced barrier membranes versus connective tissue grafts. J Periodontol 1998: 69: 383391.

59. Laney JB, Saunders VG, Garnick JJ. A comparison of two techniques for attaining root coverage. J Periodontol 1992: 63: 19-23.

60. Langer B, Langer L. Subepithelial connective tissue graft technique for root coverage. J Periodontol 1985: 56: 715720 .

61. Levin RA. Covering denuded maxillary root surfaces with the subepithelial connective tissue graft. Compendium Contin Educ Dent 1991: 12: 568-577.

62. Liu WJ, Solt CW. A surgical procedure for the treatment of localized gingival recession in conjunction with root surface citric acid conditioning. J Periodontol 1980: 51: 505-509.

63. Matarasso S, Cafiero C, Coraggio F, Vaia E, de Paoli S. Guided tissue regeneration versus coronally repositioned flap in the treatment of recession with double papillae. Int J Periodontics Restorative Dent 1998: 18: 444-453.

64. Marggraf E. A direct technique with a double lateral bridging flap for coverage of denuded root surface and gingiva extension. Clinical evaluation after 2 years. J Clin Periodontol 1985: 12: 69-76.

65. McGuire MK. Periodontal plastic surgery. Dent Clin North Am 1998: 42: 411-465.

66. Michaelides PL, Wilson SG. An autogenous gingival graft technique. Int J Periodontics Restorative Dent 1994: 14: 112-125.

67. Milano F. A combined flap for root coverage. Int J Periodontics Restorative Dent 1998: 18: 544-551.

68. Miller PD. A classification of marginal tissue recession. Int J Periodontics Restorative Dent 1985: 5: 9-14.

69. Miller PD. Root coverage using the free soft tissue autograft following citric acid application. III. A successful and predictable procedure in area of deep-wide recession. Int J Periodontics Restorative Dent 1985: 5: 15-37.

70. Mörmann W, Cianco SG. Blood supply of human gingiva following periodontal surgery. A fluorescein angiographic study. J Periodontol 1977: 48: 681-692.

71. Müller HP, Eger T, Schorb A. Gingival dimensions after root coverage with free connective tissue grafts. J Clin Periodontol 1998: 25: 424-430.

72. Müller HP, Stahl M, Eger T. Root coverage employing an envelope technique or guided tissue regeneration with bioabsorbable membrane. J Periodontol 1999: 70: 743-751.

73. Nelson SW. The subpedicle connective tissue graft. A bilaminar reconstructive procedure for the coverage of denuded root surfaces. J Periodontol 1987: 58: 95-102.

74. Oles RD, Ibbott CG, Laverty WH. Effects of citric acid treatments on pedicle flap coverage of of localized recession. J Periodontol 1985: 56: 259-261.

75. Oliver RG, Löe H, Karring T. Microscopic evaluation of the healing and re-vascularization of free gingival grafts. J Periodontal Res 1968: 3: 84-95.

76. Ouhayoun J-P, Khattab R, Serfaty R, Feghaly-Assaly M, Sawaf $\mathrm{MH}$. Chemically separated connective tissue grafts: clinical application and histological evaluation. J Periodontol 1993: 64: 734-738.

77. Page RC, Offenbacher S, Schroeder HE, Seymour GJ, Kornman KS. Advances in the pathogenesis of periodontitis: summary of developments, clinical implications and future directions. Periodontol 2000 1997: 14: 216-248. 
78. Paolantonio M, di Murro C, Cattabriga A, Cattabriga M. Subpedicle connective tissue graft versus free gingival graft in the coverage of exposed root surfaces. A 5-year clinical study. J Clin Periodontol 1997: 24: 51-56.

79. Patur B. The rotation flap for covering denuded root surfaces. A closed wound technique. J Periodontol 1977: 48: 41-44.

80. Pennel BM, Higgison JD, Towner TD, King KO, Fritz BD, Salder JF. Oblique rotated flap. J Periodontol 1965: 36: 305309.

81. Pini Prato GP, Tinti C, Vincenzi G, Magnani C, Cortellini P, Clauser C. Guided tissue regeneration versus mucogingival surgery in the treament of human buccal gingival recession. J Periodontol 1992: 63: 918-928.

82. Pini Prato GP, Clauser C, Magnani C, Cortellini P. Resorbable membranes in the treatment of human buccal recession. A nine-case reports. Int J Periodontics Restorative Dent 1995: 15: 258-267.

83. Pini Prato GP, Clauser C, Cortellini P, Tinti C, Vincenzi G, Pagliaro U. Guided tissue regeneration versus mucogingival surgery in the treament of human buccal recessions. A 4-year follow-up study. J Periodontol 1996: 67: 1216223.

84. Pini Prato GP, Baldi C, Pagliaro U, Nieri M, Saletta D, Rotundo R, Cortellini P. Coronally advanced flap procedure for root coverage. Treatment of root surface: root planing versus polishing. J Periodontol 1999: 70: 1064-1076.

85. Rachlin G, Koubi G, Dejou J, Franquin JC. The use of a resorbable membrane in mucogingival surgery. Case series. J Periodontol 1996: 67: 621-626.

86. Raetzke PB. Covering localized areas of root exposure employing the "envelope" technique. J Periodontol 1985: 56: 397-402.

87. Register A, Burdick F. Accelerated reattachment with cementogenesis to dentin, demineralized in situ. II. Defect repair. J Periodontol 1976: 47: 497-505.

88. Ricci G, Silvestri M, Tinti C, Rasperini G. A clinical/statistical comparison between the subpedicle connective tissue graft method and guided tissue regeneration technique in root coverage. Int J Periodontics Restorative Dent 1996: 16: $538-545$.

89. Roccuzzo M, Lungo M, Corrente G, Gandolfo S. Comparative study of a bioabsorbable and non-resorbable membrane in the treatment of human buccal gingival recessions. J Periodontol 1996: 67: 7-14.

90. Roccuzzo M, Buser D. Treatment of buccal gingival recessions with ePTFE membranes and miniscrews: surgical procedure and results of 12 cases. Int J Periodontics Restorative Dent 1996: 16: 356-365.

91. Romanos GE, Bernimoulin J-P, Marggraf E. The double lateral bridging flap for coverage of denuded root surface: longitudinal study and clinical evaluation after 5 to 8 years. J Periodontol 1993: 64: 683-688.

92. Sandhu HS, Sharma V, Sidhu GS. Role of psychiatric disorders in self-inflicted periodontal injury: a case report. J Periodontol 1997: 68: 1136-1139.

93. Sbordone L, Ramaglia L, Spagnuolo G, De Luca M. A comparative study of free gingival and subepithelial connective tissue grafts. Periodontal Case Rep 1988: 10: 8-12.

94. Sculean A, Donos N, Reich E, Brecx M, Karring T. Healing of recession-type defects following treatment with enamel matrix proteins or guided tissue regeneration. A pilot study in monkeys. J Parodontol Implantol 2000: 19: 12-20.
95. Selvig KA, Zander HA. Chemical analysis and microradiography of cementum and dentin from periodontally diseased human teeth. J Periodontol 1962: 33: 303-310.

96. Shieh A-T, Wang H-L, O'Neal RB, Glickman GN, MacNeil RL. Development and clinical evaluation of a root coverage procedure using a collagen barrier membrane. J Periodontol 1997: 68: 770-778.

97. Slots J, MacDonald ES, Nowzari H. Infectious aspects of periodontal regeneration. Periodontol 2000 1999: 19: 164172.

98. Smuckler H. Laterally positioned mucoperiosteal pedicle grafts in the treatment of denuded roots. A clinical and statistical study. J Periodontol 1976: 47: 590-595.

99. Staffileno H. Management of gingival recession and root exposure problems associated with periodontal disease. Dent Clin North Am 1964: March: 111-120.

100. Sullivan HC, Atkins JH. Free autogenous gingival grafts. I. Principles of successful grafting. Periodontics 1968: 6: 121-129.

101. Tal H. Subgingival acellular dermal matrix allograft for the treatment of gingival recession: a case report. J Periodontol 1999: 70: 1118-1124.

102. Tarnow DP. Semilunar coronally positioned flap. J Clin Periodontol 1986: 13: 182-185.

103. Tatakis DN, Trombelli L. Adverse effects associated with bioabsorbable guided tissue regeneration device in the treatment of human gingival recession defects. A clinicopathologic case report. J Periodontol 1999: 70: 542-547.

104. Tennenbaum H, Klewansky P, Roth JJ. Clinical evaluation of gingival recession treated by coronally repositioned flap technique. J Periodontol 1980: 51: 686-690.

105. Thomson MR, Garito ML, Brown FH. The role of smoking in periodontal disease: a literature review. Periodontal Abstr J West Soc Periodontol 1993: 41: 5-10.

106. Tinti C, Vincenzi G. The treatment of gingival recession with "guided tissue regeneration" procedures by means of Gore-Tex membranes. Quintessence Int 1990: 6: 465-468.

107. Tinti C, Vincenzi G, Cortellini P, Pini Prato GP, Clauser C. Guided tissue regeneration in the treatment of human facial recession. A 12-case report. J Periodontol 1992: 63: 554-560.

108. Tinti C, Vincenzi GP, Cocchettto R. Guided tissue regeneration in mucogingival surgery. J Periodontol 1993: 64: 1184-1191.

109. Tinti C, Vincenzi G. Expanded polytetrafluoroethylene titanium-reinforced membranes for regeneration of mucogingival recession defects. A 12-case report. J Periodontol 1994: 65: 1088-1094.

110. Tolmie PN, Rubins RP, Buck GS, Vagianos V, Lanz JC. The predictability of root coverage by way of free gingival autografts and citric acid application: an evaluation by multiple clinicians. Int J Periodontics Restorative Dent 1991: 11: 261-271.

111. Trombelli L, Schincaglia G, Checchi L, Calura G. Combined guided tissue regeneration, root conditioning, and fibrin-fibronectin system application in the treatment of gingival recession. A 15-case report. J Periodontol 1994: 65: 796-803.

112. Trombelli L, Schincaglia GP, Scapoli C, Calura G. Healing response of human buccal gingival recessions treated with ePTFE membranes. A retrospective report. J Periodontol 1995: 66: 14-22.

113. Trombelli L, Scabbia A, Wikesjö UME. Fibrin glue appli- 
cation in conjunction with tetracycline root conditioning and coronally positioned flap procedure in the treatment of human gingival recession defects. J Clin Periodontol 1996: 23: 861-867.

114. Trombelli L, Scabbia A. Healing response of gingival recession defects following guided tissue regeneration procedures in smokers and non-smokers. J Clin Periodontol 1997: 24: 529-533.

115. Trombelli L, Scabbia A, Tatakis DN, Checchi L, Calura G. Resorbable barrier membrane and envelope flap surgery in human gingival recession defects. A case report. J Clin Periodontol 1998: 25: 24-29.

116. Trombelli L, Scabbia A, Tatakis DN, Calura G. Subpedicle connective tissue graft versus guided tissue regeneration procedure with bioabsorbable membrane in the treatment of human gingival recession defects. J Periodontol 1998: 69: 1271-1277.

117. Wennström JL. Proceedings of the 1996 World Workshop in Periodontics. Ann Periodontol 1996: 1: 667-701.

118. Wennström JL, Zucchelli G. Increased gingival dimensions. A significant factor for successful outcome of root coverage procedures? A 2-year prospective clinical study. J Clin Periodontol 1996: 23: 770-777.
119. Wennström JL, Pini Prato GP. Mucogingival therapy. In: Lindhe J, ed. Clinical periodontology and implant dentistry. 3rd edn. Munksgaard: Copenhagen, 1997: 550-596.

120. Wikesjö UME, Nilvéus RE, Selvig KA. Significance of early healing events on periodontal repair: a review. J Periodontol 1992: 63: 158-165.

121. Wikesjö UME, Selvig KA. Periodontal wound healing and regeneration. Periodontol 2000 1999: 19: 21-39.

122. Zabalegui I, Sicilia A, Cambra A, Gil J, Sanz M. Treatment of multiple adjacent gingival recessions with the tunnel subepithelial connective tissue graft: a clinical report. Int J Periodontics Restorative Dent 1999: 19: 199-206.

123. Zade RM, Hirani SH. A clinical study of localized gingival recession treated by lateral sliding flap. J Indian Dent Assoc 1985: 57: 19-26.

124. Zahedi S, Bozon C, Brunel G. A 2-year clinical evaluation of a diphenylphosphorylazide-cross-linked collagen membrane for the treatment of buccal gingival recession. J Periodontol 1998: 69: 975-981.

125. Zucchelli G, Clauser C, De Sanctis M, Calandrello M. Mucogingival versus guided tissue regeneration procedures in the treatment of deep recession type defects. J Periodontol 1998: 69: 138-145. 